\title{
Review
}

\section{Putative pathophysiological role of growth factors and cytokines in experimental diabetic kidney disease}

\author{
A. Flyvbjerg \\ Medical Research Laboratory M (Diabetes and Endocrinology) and Medical Department M (Diabetes and Endocrinology), \\ Institute of Experimental Clinical Research, University of Aarhus, Aarhus Community Hospital, Aarhus, Denmark
}

\section{Abstract}

The development of diabetic nephropathy in patients with Type I (insulin-dependent) and Type II (non-insulin-dependent) diabetes mellitus is still a huge clinical problem associated with increased morbidity and mortality. The mechanisms underlying the development of diabetic kidney disease are extremely complex and yet not completely understood. Among many potential pathogenic mechanisms responsible for the development of diabetic kidney disease, various growth factors have been suggested to be important players. In particular, growth hormone $(\mathrm{GH}) / \mathrm{in}$ sulin-like growth factors (IGFs), transforming growth factor $\beta$ (TGF- $\beta$ ), vascular endothelial growth factor (VEGF) and epidermal growth factor (EGF) have measurable effects on the development of experimental diabetic kidney disease through complex intra-renal systems. Recent findings that these growth factors might initiate the early diabetic renal changes have provided insight into processes that might be relevant for future development of new drugs useful in the treatment of diabetic kidney disease. As will appear from the present review, enhanced understanding of the cellular mechanisms responsible for the development of diabetic kidney disease has already allowed the design of specific antagonists of pathophysiologically increased growth factors. Recent studies have shown that treating experimental diabetic models with such antagonists is followed by renoprotection. [Diabetologia (2000) 43: 1205-1223]

Keywords Growth hormone, insulin-like growth factors, transforming growth factor $\beta$, vascular endothelial growth factor, epidermal growth factor, antagonist, angiotensin converting enzyme inhibition, protein kinase $\mathrm{C}$ inhibition, nephropathy, somatostatin analogue.

\section{Introduction}

Diabetic nephropathy is one of the most common causes of end-stage renal failure in the Western world [1-5]. The characteristic early changes of the diabetic

Corresponding author: A. Flyvbjerg, MD, DMSc. Associate professor, Specialist in Endocrinology and Internal Medicine, Medical Research Lab. M (Diabetes and Endocrinology) and Medical Department M (Diabetes and Endocrinology), Aarhus Kommunehospital, Nørrebrogade 44, DK-8000 Aarhus C, Denmark

Abbreviations: ACEi, Angiotensin converting enzyme inhibitor; bGH, bovine GH; DAG, diacylglycerol; ECM, extracellular matrix; EGFr, epidermal growth factor receptor; $\mathrm{GH}$, growth hormone; GHBP, GH binding protein; GHR, GH receptor; IGFBPs, IGF binding proteins; IGF-IR, IGF-I recep- kidney disease are increased renal size, glomerular volume and hyperfiltration. Later on in the incipient stage an increase in albumin excretion rate (AER) is followed by development of mesangial proliferation,

tor; IGF-II/man-6-PR, IGF-II/mannose-6-phosphate receptor; $\mathrm{KO}$, knockout; MAP kinase, mitogen-activated protein kinase; $\mathrm{NF}-\varkappa \mathrm{B}$, nuclear factor- $\varkappa \mathrm{B}$; NOD, non-obese diabetic; NSILA, non-suppresible insulin-like activity; OLETF Rat, OtsukaLong-Evans-Tokushima Fatty Rat; PKC, protein kinase C; SF, sulphation factor; STZ, streptozotocin; TG, transgenic; TGF$\beta$ type RI, TGF- $\beta$ type I receptor; TGF- $\beta$ type RII, TGF- $\beta$ type II receptor; TGF- $\beta$ type RIII, TGF- $\beta$ type III receptor; VEGF, vascular endothelial growth factor; VEGFR, vascular endothelial growth factor receptor 
glomerular extracellular matrix (ECM) accumulation and glomerular sclerosis. Overt diabetic nephropathy is clinically characterized by proteinuria, hypertension and a progressive renal insufficiency [1-5]. The search for important pathogenic mechanisms in diabetic kidney disease has focused on the early events, at the time when the above mentioned pathophysiological changes take place. Several metabolic, functional and structural renal changes in diabetic rodents have fundamental similarities to those occurring in diabetic patients and accordingly rats and mice with spontaneously developing diabetes or diabetes induced by streptozotocin (STZ) have been used extensively in diabetes research aiming at explaining the pathogenesis of diabetic kidney disease. These diabetic rodents develop renal enlargement, glomerular hypertrophy and renal hyperfiltration within weeks after diabetes debut and increased AER, glomerular ECM accumulation, increased glomerular basement membrane thickness and mesangial proliferation within months [6].

Due to their growth-promoting and proliferative effects, growth factors and cytokines have attracted attention in various aspects of diabetes research including conceivable effects on functional and structural changes in the development of diabetic kidney disease. The term growth factor is used as a generic designation of any substance capable of inducing cellular proliferation and differentiation and it embraces an ever increasing number of peptides found in the circulation and in different tissues, including the kidney. In their role as mediators, certain growth factors extend the known cascade that begins with hypothalamic releasing factors, that flows through the pituitary trophic hormones to endocrine gland hormones released into the circulation, and culminates with periferal tissue growth. Some growth factors do not, however, mediate their actions as hormones because their effects are mediated directly through paracrine/autocrine mechanisms.

Viewed historically, growth hormone $(\mathrm{GH})$ is the growth factor with the longest association to diabetes. The anterior pituitary became interesting when Young in 1937 showed that anterior pituitary extracts precipitated diabetes in dogs [7] and attention was focussed on GH 50 years ago, when it was shown that daily injections of highly purified GH made dogs permanently diabetic [8]. The discovery that induced further interest in $\mathrm{GH}$ and diabetes was that diabetic patients present with substantial GH hypersecretion $[9$, 10]. At the same time the 'GH-hypothesis' that $\mathrm{GH}$ plays an important part in the development of diabetic microangiopathy was launched [11]. The role of insulin-like growth factors (IGFs) and diabetes seems to be much shorther, although as early as 30 years ago studies on sulphation factor (SF) or non-suppresible insulin-like activity (NSILA) in diabetic patients were done oblivious of their partial identity with
IGFs [12]. Yde was the first to show that the SF was abnormal in diabetic serum, with a negative correlation with metabolic control [12]. Today it is generally believed that metabolic deterioration in diabetes first decreases hepatic IGF-I formation and serum IGF-I concentration, which then secondarily induces $\mathrm{GH}$ hypersecretion through an intact feedback mechanism [13, 14]. Increased circulating GH concentrations are then believed to stimulate local IGF-I concentrations in non-hepatic tissues (e.g. in the kidney) as discussed in detail below.

In the last 10 to 15 years great progress and new information have been generated in a constantly increasing number of publications on the possible relation between changes in growth factors and diabetic complications. This progress has mainly been facilitated by the development of new techniques allowing isolation and purification of growth factors and because modern molecular and cellular techniques have been developed. This review will present an update of the published evidence for a pathophysiological relation between changes in circulating and intrarenal growth factors and development of early diabetic renal changes in animal models. The first part of the review presents data on a definitive role of the GH/IGF system in the pathogenesis of the renal changes in experimental diabetes focussing on the renoprotective effects of long-acting somatostatin analogues and GH-receptor (GHR) antagonists. In the second part data suggesting a causal role for transforming growth factor $\beta$ (TGF- $\beta$ ) in the pathogenesis of diabetic renal changes is presented, with emphasis on the possible close relation between TGF- $\beta$ and the renin angiotensin and protein kinase $\mathrm{C}$ (PKC) systems. In the third and fourth part evidence for the roles of vascular endothelial growth factor (VEGF) and epidermal growth factor (EGF) being involved in the development of diabetic kidney disease is given. The present review will focus on data obtained in experimental diabetic models as only few clinical studies have been published on this topic.

\section{Growth hormone (GH) and insulin-like growth factors (IGFs)}

\section{The GH/IGF system}

The GH/IGF system constitutes a complex system of peptides in the circulation, extracellular space and in most tissues (Fig. 1). The classic endocrine effect of pituitary secreted GH is the induction of IGF-I synthesis in various organs through activation of specific GHRs. The GHR consists of intracellular, transmembrane and extracellular components. In humans the latter is identical to the $\mathrm{GH}$ binding protein (GHBP), produced by a post-translational cleavage of the extracellular component, which is shed to the 


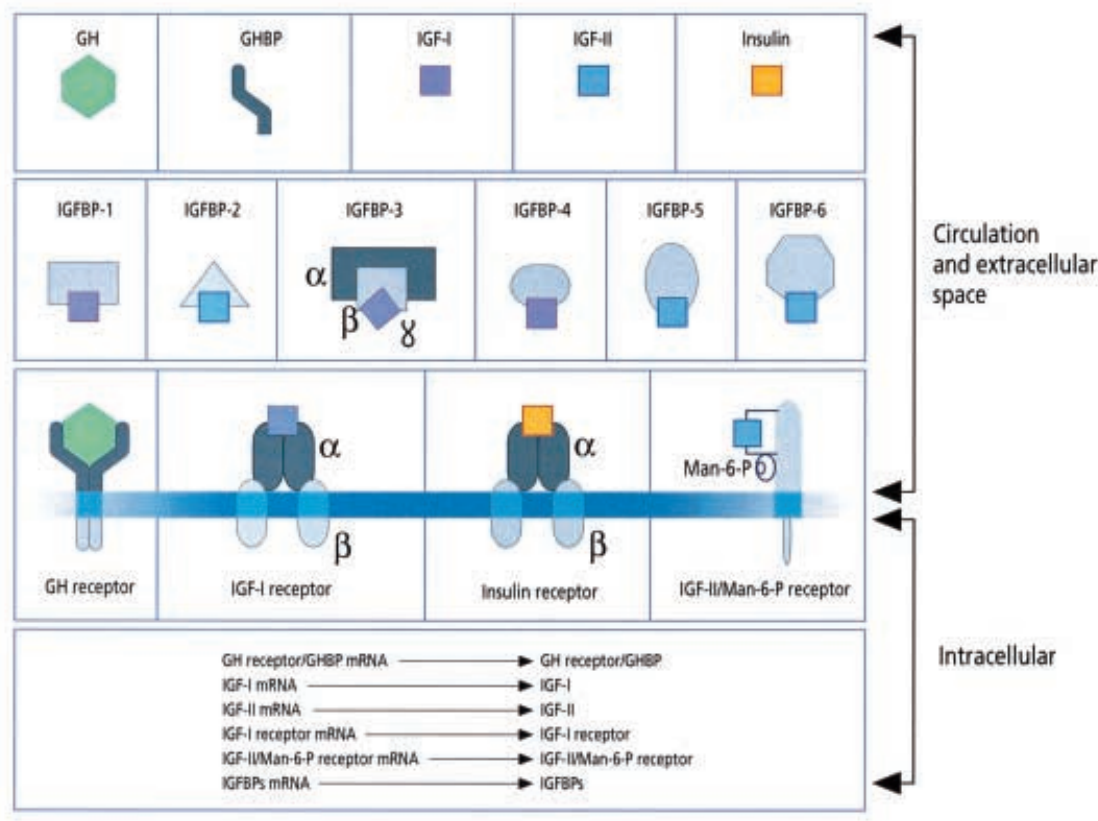

Fig. 1. Schematic depiction of the growth hormone $(\mathrm{GH}) /$ insulin-like growth factor (IGF) axis. GHBP: GH binding protein; IGF-I: insulin-like growth factor I; IGF-II: insulin-like growth factor II; IGFBP-1 to -6 : IGF binding protein-1 to -6 ; IGF-II/ man-6PR: IGF-II/mannose-6-phosphate receptor; mRNA: messenger RNA. For further explanation and references see text

circulation. In rodents both GHR and GHBP are, however, products of alternate splicing of a single gene $[15,16]$. The effects of IGF-I and IGF-II are mediated through two specific IGF receptors [17-19]. The IGF-I receptor (IGF-IR) (also known as the type 1 IGF receptor) has a high degree of homology with the insulin receptor, with two extracellular IGFI binding $\alpha$-subunits, two transmembrane $\beta$-subunits linked together by disulphide bonds and with intracellular tyrosine kinase activity. The IGF-II/mannose 6-phosphate receptor (IGF-II/man-6-PR) (also known as the type 2 IGF receptor) binds IGF-II and man-6-P and plays a part in trafficking of lysosomal enzymes. Finally, IGFs are bound to specific IGFbinding proteins (IGFBPs) of which six high-affinity (IGFBP-1 to IGFBP-6) [20, 21] and several low-affinity IGFBP-related proteins (IGFBP-rP) have been characterized [22]. In the circulation IGFBPs are believed to prolong the half-life of IGFs as well as to regulate the endocrine effects of IGFs, whereas at the cellular level the IGFBPs are believed to modulate local actions of IGFs both in an inhibitory and stimulatory fashion.

\section{Expression of the GH/IGF system in the normal kidney}

The GH/IGF-system is expressed in the normal kidney, ranging from messenger RNA (mRNA) expression for the GHR and GHBP [15, 16], IGF-I and IGF-II [23, 25], the respective IGF-IR and IGF-II/ man-6-PR [17-19] and all six specific IGFBPs [20-22]. As described previously in detail [15-28], each member of the GH/IGF axis has its specific localization in the nephron and thereby constitutes a system in which GH, GHBP and IGFs in the circulation and in the kidney could affect the nephron both through endocrine and autocrine/paracrine mechanisms.

\section{In vitro evidence for $G H / I G F$ effects on kidney cells}

Insulin-like growth factor I has been shown to exert biological effects on murine and human mesangial cell lines in vitro. A dose-dependent increase in thymidine uptake and cell number IGF-I induced by has been observed in murine mesangial cells exposed to IGF-I under serum-free conditions [29]. In addition, IGF-I has been shown to be a progression factor for human mesangial cell growth in vitro [30]. Further, IGF-I stimulates proteoglycan production by human fetal mesangial cells [31] and vascular endothelial cells [32] in culture. Notably, mesangial cells isolated from non-obese diabetic (NOD) mice (an experimental model of Type I (insulin-dependent) diabetes mellitus) showed a robust phenotypic switch in vitro, consisting of increased IGF-I synthesis and proliferation when compared with the IGF-I effect of mesangial cells from non-diabetic animals [33]. Recent in vitro data obtained in mesangial cells from 

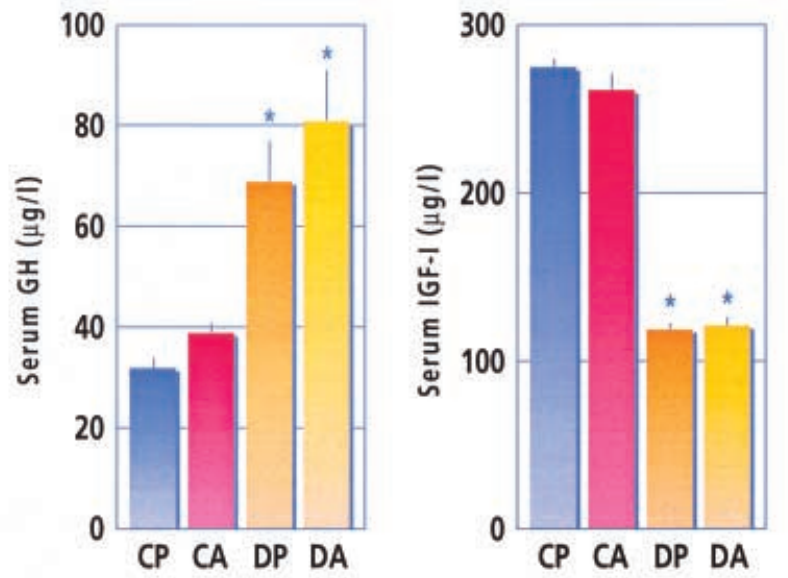

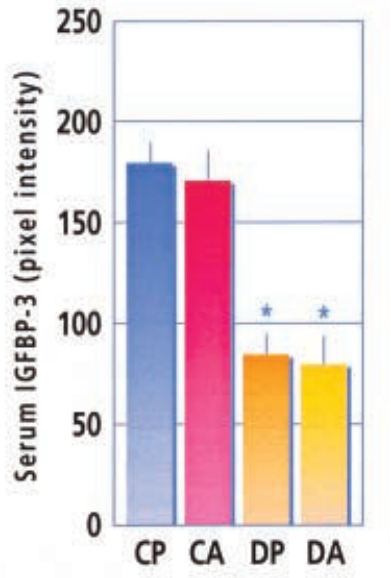

Fig. 2. Changes in serum growth hormone $(\mathrm{GH})$, insulin-like growth factor I (IGF-I) and IGF binding protein 3 (IGFBP-3) in non-diabetic mice treated with placebo $(\mathrm{CP})$ or $\mathrm{GH}$ receptor (GHR) antagonist (CA) and diabetic mice treated with placebo (DP) or GHR antagonist (DA) for 1 month. Note the increased serum GH concentrations, low serum IGF-I and IGFBP-3 concentrations in diabetic animals compared with nondiabetic controls. Adapted from [37] with permission

NOD mice, showed that excessive IGF-I production contributes to the altered ECM accumulation in NOD mice, largely through a reduction in metalloproteinase 2 (MMP-2) activity [34], giving further evidence for IGF-I being a major contributor to the development of diabetic glomerulopathy.

\section{In vivo evidence for a role of $G H / I G F$ in diabetic kidney disease}

As described above it is well known that poorly controlled diabetes in humans is characterized by $\mathrm{GH}$ hypersecretion [9-14] whereas the most widely used experimental animal model for Type I diabetes, the STZ-diabetic rat, is characterized by suppressed circulating GH concentrations, with loss of the characteristic pulsatility early after induction of diabetes [35]. The reason for this discrepancy is still controversial [36]. Just recently we discovered that diabetic mice present with GH hypersecretion and low circulating IGF-I concentrations [37], indicating that this animal strain might be a better model than the diabetic rat for the circulating pertubations in the $\mathrm{GH} /$ IGF axis seen in human diabetes (Fig. 2). It seems, however, evident that the difference in the GH/IGF axis between experimental diabetes in rats and diabetes in humans is restricted to GH. Similar changes have been reported for other elements in the $\mathrm{GH} /$ IGF axis in poorly controlled diabetic rats and humans, including changes in circulating concentrations of GHBP, IGF-I and IGFBPs [26-28, 38-40]. In addition, specific changes occur locally in the diabetic kid- ney, involving a number of complex cellular mechanisms with changes in renal GHBP, IGF receptors and IGFBPs.

Decreased serum GHBP concentrations and low hepatic GHR number are well described features in experimental diabetes [35, 38, 39, 41]. In contrast only few data have been published on the renal expression of GHR and GHBP in experimental diabetes. In one study GHR mRNA expression was measured 4 days after induction of STZ-diabetes and unchanged levels were reported, despite decreasing expression in hepatic GHR mRNA [41]. In a recent study including both short-term and long-term diabetic rats, differential changes in kidney GHR and GHBP mRNA were observed [16]. In the cortex, no change was seen in the GHR mRNA throughout the 6 months of observation, but a statistically significant increase in the GHBP mRNA was observed 1 month after induction of diabetes and sustained for the rest of the study period [16]. No changes were seen in GHR or GHBP mRNA in the medullary regions [16]. These data indicate that although the GHR and GHBP mRNAs originate from the same gene, they are differentially regulated during the development of experimental diabetic kidney disease and furthermore imply a specific functional role for GHBP. Whether the increase in renal GHBP mRNA actually enhances renal GH availability to the GHR and thereby enhances a pathophysiological role of $\mathrm{GH}$ is still not known.

It is well established that the rapid increase in renal growth and function seen in STZ diabetes is preceeded by a rise in renal tissue concentration of IGF-I reaching a maximum at 1-2 days after induction of diabetes and returning to basal concentrations after about 4 days [24, 26-28, 40-47]. The increase in renal IGF-I has recently been confirmed in STZ-diabetic mice [37] and in the spontaneous hyperglycaemic, NOD mouse [48]. The degree of kidney IGF-I accumulation $48 \mathrm{~h}$ after injection of STZ is directly proportional to the prevailing blood glucose concentration in animals with varying degrees of metabolic control [47] and strict insulin treatment abolishes 
both the increase in kidney IGF-I and renal hypertrophy $[42,43]$. Finally, IGF-I infusion into diabetic rats, commencing after the initial renal growth rate has abated, re-accelerates diabetic renal hypertrophy adding further weight to the hypothesis that IGF-I acts as a renotropic growth factor in early experimental diabetes [49].

Further evidence that IGF-I, with the modulating effect of GH, could be involved in both the shortterm and long-term renal changes is given in a series of experiments in diabetic dwarf rats. The dwarf rat strain used in these experiments is characterized by having an inherited autosomally recessive gene [50]. Homozygous dwarf rats present with an isolated $\mathrm{GH}$ deficiency with about $5-10 \%$ of normal pituitary $\mathrm{GH}$ content, low circulating GH concentrations and reduced circulating and tissue concentrations of IGF-I but otherwise normal pituitary function [50]. In short-term experiments, STZ-diabetic dwarf rats have slower and lesser initial renal and glomerular hypertrophy as well as a smaller rise in kidney IGF-I than diabetic controls with intact pituitary, indicating that $\mathrm{GH}$ itself could be involved in the modulation of renal enlargement [42]. Furthermore, long-term diabetic dwarf rats that have had diabetes for 6 months, have a smaller degree of renal and glomerular hypertrophy and rise in AER compared with the changes in pituitary intact diabetic rats [51]. One possible explanation for the early renal IGF-I accumulation in STZ diabetes is an increased local kidney IGF-I production. Support for this theory comes from a single report in short-term experimental diabetes of a short-lived increase in IGF-I mRNA [52]. This has not, however, been a consistent finding [24] and in a 6-month study in STZ-diabetic rats [23], decreased renal IGF-I mRNA expression was seen from the time of diabetes induction and was sustained for the whole study period as measured by in situ hybridization [26]. These findings indicate that the increase in renal IGF-I protein is probably not due to local IGF-I production and that accumulation of renal IGF-I is more likely to be caused by changes in renal IGF receptors and IGFBPs as discussed below.

As indicated above part of the biological actions of IGFs are mediated through their specific IGF receptors. In STZ diabetes no statistically significant changes are seen in the renal IGF-IR mRNA $[18,53]$ or receptor binding [54] within the first days after induction of diabetes. When focusing on the later phases of the diabetic glomerulopathy taking place in the months after induction of STZ diabetes, a sustained increase in kidney IGF-IR mRNA is, however, seen for up to 3 months [53]. In contrast to the IGF-IR, early increased IGF-II/man-6-PR protein concentrations and mRNA expressions [55] have been shown within the first days after induction of diabetes. These changes are specific for the kidney as no changes occur in the IGF-II/man-6-PR mRNA in lung or heart over the same period [55]. In long-term diabetes for up to 6 months no changes are, however, seen in the renal IGF-II/man-6-PR mRNA. In conclusion, these results suggest that the two structurally and functionally unrelated IGF receptors show specific time course changes over a time span of 6 months in experimental diabetes and play different parts in the development of the diabetic kidney disease. New results have shown the early renal changes in experimental diabetes are all abolished when diabetic rats are treated with a specific IGF-IR inhibitor (see below).

Concomitantly with the rise in endogenous kidney IGF-I in early STZ diabetes, an increase in kidney IGFBP species is seen [56]. This finding is corroborated by the finding of IGF-I binding in the diabetic kidney to low-molecular-weight material that could represent IGFBPs $[18,46]$. In a study describing the renal IGFBP mRNA expression in both short-term and long-term diabetes, very prominent and complex alterations in the renal IGFBP mRNAs and distribution were seen [26]. These changes included a pronounced shift in the distribution in the IGFBP-1 expression [26]. Immediately after induction of diabetes, the cortical IGFBP-1 mRNA expression showed a pronounced increase persisting for up to 6 months whereas the medullary IGFBP-1 mRNA was greatly reduced [26] (Fig. 3). In addition, a sustained increase in the medullary IGFBP-5 mRNA expression was seen but the cortical IGFBP-5 expression was decreased [26]. No great changes were seen in IGFBP2 or IGFBP-3 mRNAs although there was a sustained decrease in IGFBP-4 mRNA over the 6 months studied [26]. The pathophysiological effects of these changes in renal IGFBP expression in diabetes are not known. The striking and sustained redistribution of renal IGFBP-1 mRNA from medulla to cortex is, however, of note because recent studies have suggested that some IGFBPs, in addition to acting as carriers for IGFs, also operate as local modulators of IGF action. Such mechanisms could in particular be relevant for IGFBP-1 because it contains an Arg-Gly-Asp motif near the C-terminal, which could enable it to interact with cell surfaces and deliver IGF to adjacent IGF receptors, enhancing the subsequent binding and action of IGFs on the cell. In other studies IGFBP-1 has, however, been found to inhibit cellular IGF-I binding and action. The changes in IGFBP mRNA described above $[18,26,56]$ occurred in the very early stages of the diabetes-associated renal changes, thereby preceeding the early renal and glomerular hypertrophy. Furthermore, the changes were sustained for up to 6 months after induction of diabetes during the period when the development of diabetic glomerulopathy takes place. The IGFBP mRNA changes support the notion, both in duration and localization, that some IGFBPs are involved in the development of the renal changes in experimental diabetes. New results have shown the early rises 


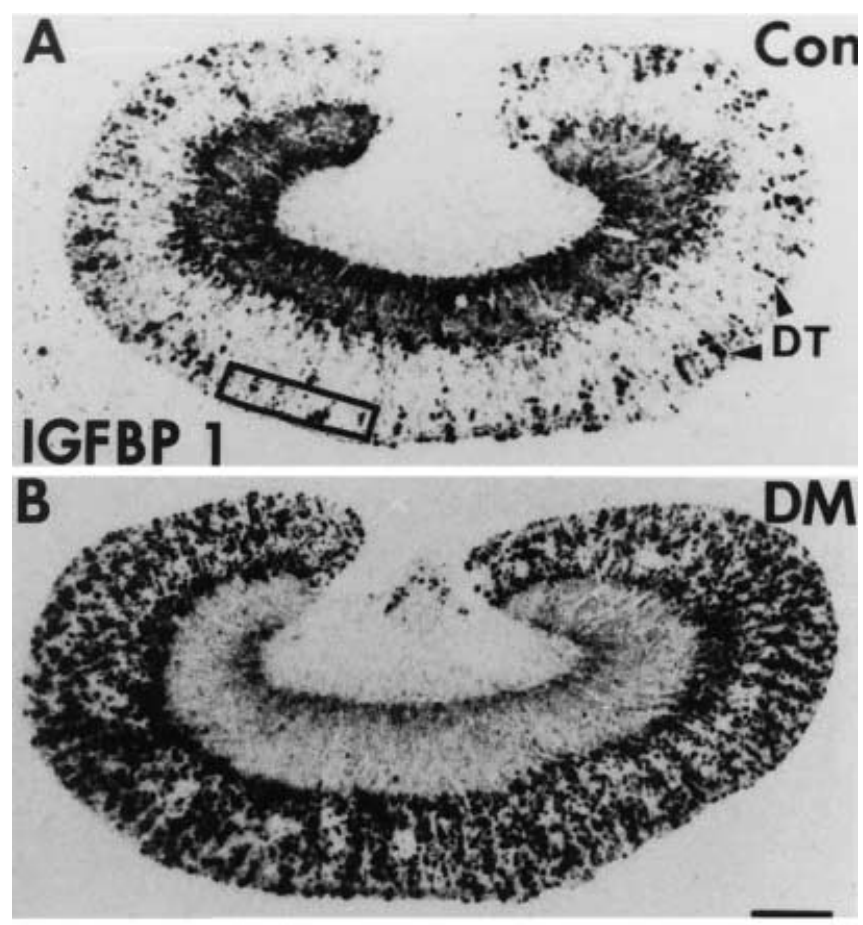

Table 1. Potential new therapeutic agents in the treatment of diabetic kidney disease: antagonists of the pathophysiologically altered growth hormone $(\mathrm{GH}) /$ insulin-like growth factor (IGF) system

Antagonists of the GHIIGF system

\section{(1) Long-acting somatostatin analogues}

(2) $\mathrm{GH}$ receptor antagonists

(3) IGF-I receptor antagonists

(4) AGE inhibition

5) ACE inhibition

For further explanation and references please see text

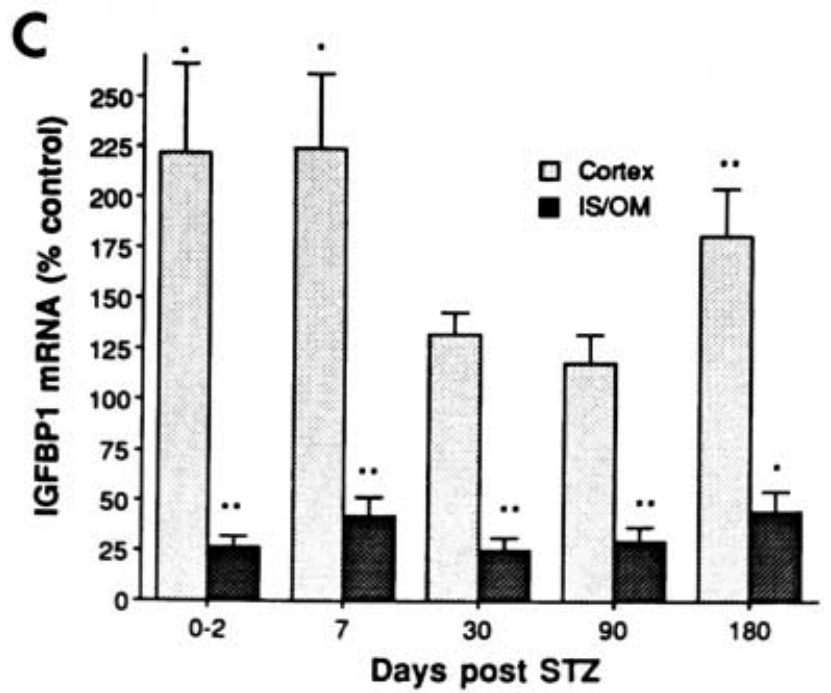

Agents with effects on the altered $G H / I G F$ axis in diabetic kidney disease

Agents that have been shown to affect the GH/IGF axis and exert beneficial renal effects in diabetic kidney disease in experimental animal models are given in Table 1. Each agent is discussed in detail below.

Long-acting somatostatin analogues. The hypothesis that somatostatin and its long-acting analogues could be used in the treatment of subjects with diabetes was initially based on the expected benefit of suppressing increased circulating $\mathrm{GH}$ concentrations in order to minimize their deleterious effects on diabetic metabolic abberration and to prevent development of long-term diabetic complications. The biological half-life of native somatostatin is too short to allow its use in clinical therapy and accordingly, long-acting somatostatin analogues (e.g. octreotide and lanreotide) have been developed and opened the possiblity of doing experimental and clinical trials. In shortterm experimental diabetes, octreotide treatment for 7 days from diabetes onset completely inhibits the initial renal hypertrophy and the kidney IGF-I accumulation in rats [40, 44]. Further, lanreotide in a dose similar to the octreotide dose given above has been shown to inhibit renal glomerular growth as well [57]. When a lower octreotide dose is used a partial inhibition of the diabetes-associated renal growth is seen, which suggests a dose dependent effect of octreotide on renal IGF-I accumulation and diabetic renal growth [58]. A series of recent experiments has shown that early intervention with somatostatin analogues after diabetes onset seems crucial for achievement of full inhibitory effects on morphological chan-

in renal IGFBP-1 mRNA, renal IGF-I and renal hypertrophy are all abolished when diabetic animal models are treated with long-acting somatostatin analogues, GHR antagonists or an inhibitor of advanced glycation end products (AGEs) (see below). 
ges. When postponing initiation of octreotide treatment 3 to 9 days after diabetes induction the early diabetic renal hypertrophy is only partly inhibited, indicating that early intervention with somatostatin analogues is important [59]. Similar results were observed in a study in which octreotide treatment was initiated for 3 weeks after a period of untreated diabetes for 3 or 6 months, as a tendency only towards a reduction in renal volume was observed [60]. The effects of somatostatin analogues on circulating and local IGFBPs in diabetes have only been examined to a limited extent. Lanreotide has been shown to inhibit the diabetes-associated increase in serum $30000 \mathrm{M}_{\mathrm{r}}$ IGFBP species (containing IGFBP-1) in rats and further to reduce serum IGFBP-3 [57]. In addition, octreotide inhibits the increased renal IGFBP1 mRNA expressions in early experimental diabetes, with no effect on hepatic IGFBP-1 mRNA expressions [61]. This is in contrast to the effect of octreotide on IGFBP-1 mRNA expressions in non-diabetic rats, in which a dose-dependent stimulatory effect of octreotide on hepatic IGFBP-1 mRNA is seen along with unchanged renal IGFBP-1 mRNA expressions [62]. Accordingly, it can be hypothesized that somatostatin analogues prevent some of the classic early diabetic renal changes by inhibiting the renal IGF-I accumulation through mechanisms involving effects on renal IGFBPs.

The effects of somatostatin analogue treatment on diabetic renal morphological and functional changes have also been examined in long-term experimental diabetes. Treatment with octreotide for 6 months from the day of diabetes induction is followed by statistically significant reductions of increase in kidney weight, kidney IGF-I concentrations and AER compared with untreated diabetic rats [63]. In addition, diabetic rats treated for 5 weeks with octreotide from diabetes onset showed a reduction in renal glomerular growth [64]. When octreotide treatment for 14 weeks was initiated in unilaterally nephrectomized diabetic rats on the day of diabetes induction 3 days after the nephrectomy, no effect of octreotide treatment on renal hypertrophy, AER or glomerular hyperfiltration was, however, observed [64]. In some studies $[65,66]$ octreotide treatment for 2-3 weeks was followed by diminished kidney hypertrophy and albuminuria in uninephrectomized-diabetic rats after 15 weeks of untreated diabetes. A recent study from our group aimed at examining the effect of 3 weeks of treatment with octreotide and an angiotensin-converting enzyme inhibitor (ACEi) (captopril) either alone or in combination after 3 months of untreated diabetes [67]. Octreotide treatment alone and in combination with captopril induced a statistically significant reduction in kidney weight compared with diabetic animals treated with placebo [67]. Further, the combined treatment of octreotide and captopril was followed by a statistically significant reduction in
AER compared with diabetic rats treated with placebo giving evidence for a definite effect of the combined treatment with octreotide and captopril on manifest experimental diabetic renal changes [67].

GH-receptor antagonists. A series of highly specific antagonists of the $\mathrm{GH}$ action has recently been developed for the potential therapeutic use in various pathophysiological conditions, including diabetes. Initially it was shown that alteration of single amino acids in the third $\alpha$-helix of bovine (b) GH (residues 109-126) results in a GH antagonist [68, 69]. In vitro experiments showed that this new group of GH antagonists binds to the GH receptor with the same affinity as native $\mathrm{GH}$ but in vivo a phenotypic dwarf animal characterized by low circulating IGF-I concentrations and a proportional body composition develops when the $\mathrm{GH}$ antagonist is expressed in transgenic (TG) mice [68, 69]. Studies in long-term diabetic $\mathrm{GH}$ antagonist TG mice, that express the GH antagonist (bGH-G119R or hGH-G120R), have shown that these animals are protected against development of diabetic renal changes $[70,71]$. Compared with TG diabetic mice expressing wild-type bGH or bGH, the diabetic mice expressing $\mathrm{GH}$ antagonists showed less glomerular damage, no increase in total urine protein, no glomerular hypertrophy and no increase in glomerular $\alpha 1$ type IV collagen mRNAs [70, 71]. The inhibitory effects of GH antagonists in transgenic mice were seen without alteration in glycaemic control as similar concentrations in blood glucose, insulin and $\mathrm{HbA}_{1 \mathrm{c}}$ were seen in the different diabetic animals expressing wild-type bGH, $\mathrm{GH}$ antagonists or bGH $[70,71]$. These results are further supported by data obtained in a recent study in diabetic $G H R /$ $G H B P$ knockout (KO) mice, where disruption of the $G H R / G H B P$ gene was followed by protection against diabetes-induced renal changes, despite equivalent levels of hyperglycaemia [72]. Theoretically GH antagonist TG mice and GHR/GHBP KO mice could, however, be less susceptible to diabetic renal changes because of effects of $\mathrm{GH}$ receptor blockade and low circulating IGF-I concentrations before the induction of diabetes. Furthermore, the renal effects might be mediated indirectly through the low serum IGF-I concentrations themselves at the time of diabetes induction. To investigate the potential usefulness of $\mathrm{GH}$ antagonists as a therapeutic agent in diabetic kidney disease for tolerance and specificity, we recently did a series of studies with exogenous treatment of a long-acting $\mathrm{GH}$ antagonist (G120K-PEG) to diabetic mice $[37,73,74]$. In the initial experiment non-diabetic and STZ-diabetic mice were treated with the GH antagonist for 1 month after diabetes induction [37]. In GH antagonist-treated diabetic mice, renal IGF-I accumulation, renal enlargement and glomerular hypertrophy were abolished and the diabetes-associated increase in AER 


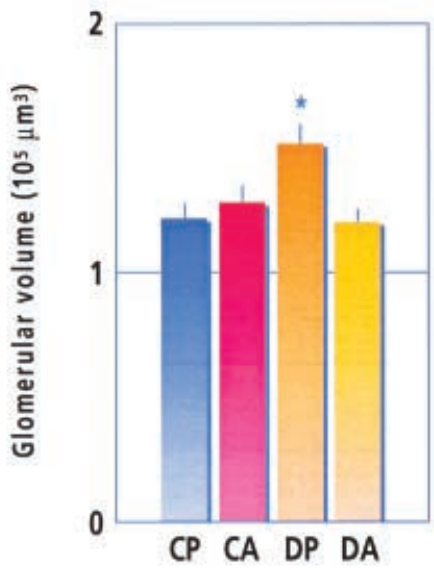

Fig. 4. Inhibitory effect of a specific growth hormone receptor (GHR) antagonist of the diabetes associated glomerular hypertrophy and rise in urinary albumin excretion (UAE) in non-diabetic mice treated with placebo (CP) or GHR antagonist (CA) and diabetic mice treated with placebo (DP) or GHR antagonist (DA). Adapted from [37] with permission

was also reduced [37] (Fig.4). These effects were achieved through a specific mechanism at the renal GHR level, as no effect of treatment was seen on changes in body weight, food consumption, metabolic control, serum GH or IGF-I [37] (Fig. 2). These results have been confirmed in NOD mice [73]. In a recently conducted experiment the effect of GH antagonism alone or in combination with ACEi treatment was examined on manifest renal changes in NOD mice [74]. Preliminary results showed that GH antagonist treatment was as potent as ACEi treatment in reducing AER [74].

IGF-I receptor antagonists. Through a three-dimensional modelling of the IGF-I protein, the synthesis of selective antagonists of the IGF-I receptor (by mimicking the D-domain of IGF-I) have been designed [75]. The series of IGF-I receptor antagonists include 12 amino-acid cyclic peptides one of which (JB3) is synthesized from D-isomer rather than L-isomer to reduce suseptibility to proteolytic degradation [75]. The JB3 peptide can therefore be used in vivo and in a recent study in short-term experimental diabetes in rats, the diabetes-induced rise in renal size, kidney protein and DNA were all normalized by JB3 treatment [77]. The effects of long-term JB3 treatment in experimental models of diabetes are not known. Notably, in a recent study using a model of non-diabetic retinopathy in rats, treatment with JB3 suppressed retinal neovascularization and in addition, suppressed the rise in retinal VEGF suggesting VEGF is a downstream mediator of IGF-I effects [78] (see also below). Further, both IGF-I [79] and VEGF [80] have been shown to stimulate nuclear fac-

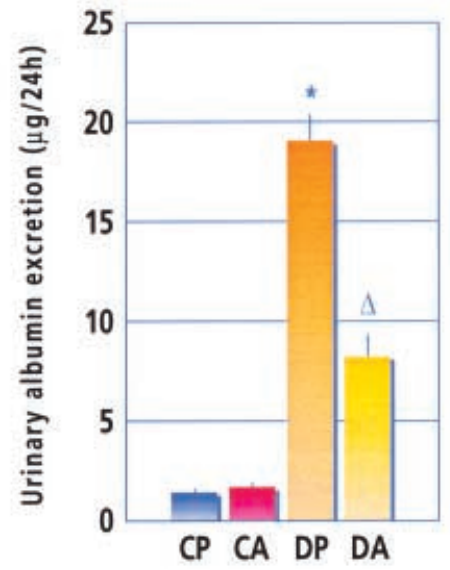

tor- $x \mathrm{~B}(\mathrm{NF}-\varkappa \mathrm{B})$ concentrations in cultured endothelial cells, adding more weight to the hypothesis of an interrelation between the two systems in retinal pathology. Whether these pathways are also operative in mediating the GH and IGF-I effects in diabetic renal changes is not known.

Advanced glycation end-product (AGE) inhibition. Increased formation of advanced glycation end products (AGEs) is a common phenomenon in diabetes with possible implications in the development of diabetic complications, including diabetic kidney disease. The formation of AGEs arise from a non-enzymatic reaction between glucose and biologically relevant structural proteins. Advanced glycation end products are known to mediate their effects both through receptor-dependent and receptor-independent mechanisms and in vitro evidence seems to indicate that AGEs also stimulate the synthesis of various growth factors, including IGF-I and TGF- $\beta$ (see also below). Notably, a recent study in long-term STZ-diabetic rats [81] showed the classic changes in the intrarenal IGF axis, with decreased IGF-I mRNA [24, 26] and IGFBP-4 mRNA [26] and increased IGFBP1 mRNA expression over a diabetes duration of 8 months [26]. Oral treatment with aminoguanidine, a potent inhibitor of AGE formation with renoprotective actions [81], reduced renal IGFBP-1 mRNA expression to normal, along with partial restoration to normal of diabetes-associated changes in IGFBP4 and IGF-I mRNA [81]. The partial restoration to normal of the diabetes-associated changes in the IGF system could contribute to the aminoguanidineinduced renoprotection.

Angiotensin converting enzyme (ACE) inhibition. The possible effects of ACEi on the GH/IGF axis in diabetic kidney disease have not been examined extensively. In one short-term experimental study, trandolapril treatment for 1 week had no effect on renal IGF-I accumulation or renal changes, despite a pronounced reduction in renal ACE activity [82]. Still as mentioned above, late intervention with an ACEi 


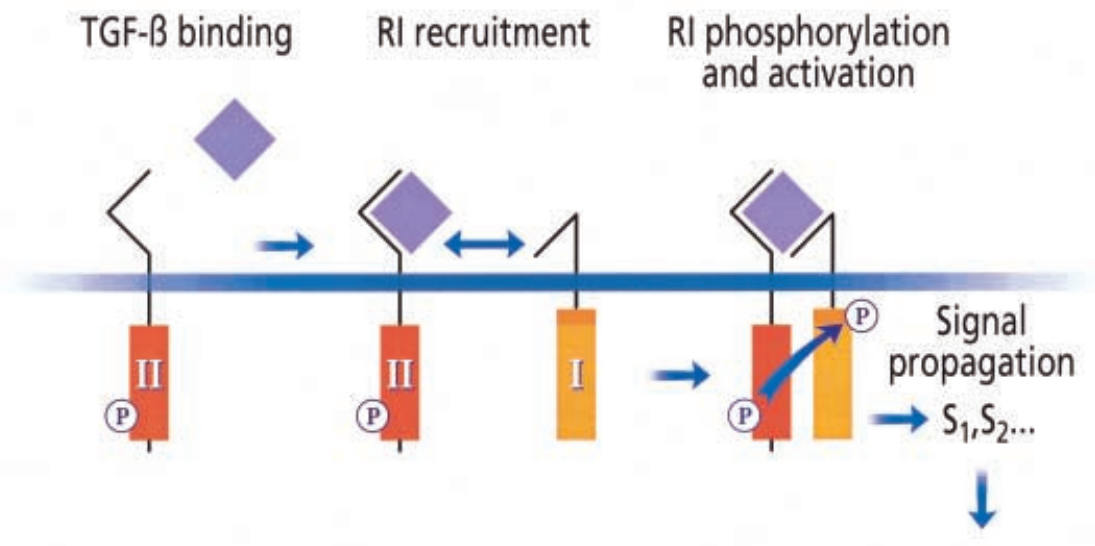

Fig. 5. Schematic depiction of signalling through the transforming growth factor $\beta$ (TGF- $\beta$ ) receptors. After initial binding of TGF- $\beta$ to the TGF- $\beta$ Type II receptor (II), the TGF- $\beta$ / TGF- $\beta$ Type II receptor complex binds to the TGF- $\beta$ Type I receptor (I) with subsequent phosphorylation of the latter and intracellular signalling. Adapted from [84] with permission

and a long-acting somatostatin analogue, octreotide, given either alone or in combination, monotherapy with either drug had no effects on renal IGF-I concentrations or functional variables although attenuating effects of these drugs were seen when given in combination [67]. These data indicate that, although the renoprotective effects of ACEis on early renal changes in diabetes might not be mediated through the IGF-I system, they could still be effective, even on manifest renal changes, when the two different therapeutic regimens are applied [67].

\section{Transforming growth factor $\beta$ (TGF- $\beta$ )}

\section{The TGF- $\beta$ system}

The TGF- $\beta$ s belong to a superfamily of several related proteins, including three mammalian TGF- $\beta$ isoforms (TGF- $\beta 1$, TGF- $\beta 2$, and TGF- $\beta 3$ ), activins, inhibins and bone morphogenic proteins. The TGF- $\beta$ isoforms are members of a family of cell regulatory proteins that are unique among growth factors in their broad effects on extracellular matrix. Transforming growth factor- $\beta 1$ is a $25000 \mathrm{M}_{\mathrm{r}}$ homodimer polypeptide, synthesized as an inactive precursor protein which possibly binds to a TGF- $\beta$-binding protein of $125000 \mathrm{M}_{\mathrm{r}}$ and is proteolytically changed into its active form [83]. The two other TGF- $\beta$ isoforms (TGF$\beta 2$ and TGF- $\beta 3$ ) are believed to be activated the same way as TGF- $\beta 1$. The manner in which TGF- $\beta$ isoforms induce intracellular signalling through a complex cascade of receptor binding involving two different types of TGF- $\beta$ receptors has been shown experimentally [84] (Fig. 5). In brief, TGF- $\beta$ binds di- rectly to the TGF- $\beta$ type II receptor (TGF- $\beta$ type IIR) which is a constitutively active kinase. The TGF- $\beta$ bound to the type II receptor is then recognized by the TGF- $\beta$ type I receptor (TGF- $\beta$ type IR) which is recruited to form a ternary complex with subsequent phosphorylation of the TGF- $\beta$ type IR and induction of intracellular signalling [84].

\section{Expression of the TGF- $\beta$ system in the normal kidney}

The kidney is a site of TGF- $\beta$ production and a target of TGF- $\beta$ action, as both mRNA for TGF- $\beta$ isoforms and receptors and the active TGF- $\beta$ proteins have been shown in all cell types of the glomerulus [84-88] and proximal tubular cells, including localization in both nuclei and cytoplasma $[88,89]$. In a recent study from our group a full characterization of the renal distribution of all three TGF- $\beta$ isoforms and the three TGF- $\beta$ Rs was done in normal and diabetic rats [88] (see also below).

\section{In vitro evidence for TGF- $\beta$ effects on kidney cells}

In vitro, TGF- $\beta$ has been shown to modulate extracellular matrix production and notably both glomerular mesangial and epithelial cells increase synthesis of extracellular matrix proteins including protoglycans, fibronectin, type IV collagen and laminin in response to TGF- $\beta$ [90-92]. In addition, TGF- $\beta$ inhibits the synthesis of collagenases and stimulates tissue production of metalloproteinase inhibitors [93, 94]. Both these mechanisms could lead to a reduced degradation of ECM and possibly contribute to matrix accumulation. Evidence has been published recently for TGF- $\beta$ playing a part in different forms of kidney diseases characterized by changes in structure and ECM. In cultured glomerular cells obtained from immunologically induced glomerulonephritis, increased amounts of active TGF- $\beta$ can be detected [95].

In addition, there is in vitro evidence for TGF- $\beta$ playing a part in the development of diabetic nephropathy. High glucose concentrations increase TGF- 
Table 2. Potential new therapeutic agents in the treatment of diabetic kidney disease: antagonists of the pathophysiologically altered transforming growth factor $\beta$ (TGF- $\beta$ ) system

Antagonists of the TGF- $\beta$ system

\section{(1) Neutralizing TGF- $\beta$ antibodies}

\section{(2) ACE inhibition}

\section{(3) PKC $\beta$ inhibition}

\section{(4) AGE inhibition}

For further explanation and references please see text

$\beta 1$ mRNA expression in both cultured mesangial cells and proximal tubular cells in vitro [85-89]. Further, increased glucose concentrations in vitro stimulate TGF- $\beta$ mRNA expression and bioactivity, cellular hypertrophy and collagen transcription in proximal tubules [89] in addition to increased mesangial production of heparan sulphate proteoglycan [96].

In vivo evidence for a role of the TGF- $\beta$ system in diabetic kidney disease

Other than the in vitro studies mentioned above reports have been published recently on changes in renal TGF- $\beta$ in experimental short-term diabetes in vivo. In a study in STZ-diabetic rats, an increase in glomerular TGF- $\beta 1$ mRNA was reported as early as 24 hours after the onset of hyperglycaemia [97]. The animals were followed for up to 2 weeks with a sustained rise for the whole period and a threefold increase in glomerular TGF- $\beta 1$ concentrations could be shown by use of immunohistochemistry [97]. Intensive insulin treatment to restore blood glucose concentrations to normal attenuated the rise in glomerular TGF- $\beta$ expression [97]. Increased renal expressions of TGF- $\beta 1$ mRNA in the early course of diabetes-associated renal hypertrophy have also been described in the NOD mouse $[98,99]$ and the diabetic $B B$ rat (an experimental model of Type I diabetes) [97]. In addition, a sustained increase in glomerular TGF- $\beta 1$ mRNA expressions in long-term STZ-diabetic rats with a diabetes duration for up to 24 weeks has been described [85]. Further, in a non-diabetic transgenic mouse model overexpressing glomerular TGF- $\beta 1$, accumulation of extracellular matrix components (i.e. laminin and collagen IV) was observed [100]. Previous studies [85, 97-99], have focussed on changes in only one TGF- $\beta$ isoforms (i.e. TGF- $\beta 1$ ) and, in most studies, only the mRNA expressions were examined. This provided us with the impetus to carry out a rigorous characterization of the changes in the whole TGF- $\beta$ system [i.e. TGF- $\beta 1$, TGF- $\beta 2$, TGF- $\beta 3$ isoforms and TGF- $\beta$ type RI, RII and TGF$\beta$ type III receptors (RIII's)] in acute and chronic diabetes [88]. The results showed that of all the components of the TGF- $\beta$ axis studied, the TGF- $\beta 1$ and TGF- $\beta 2$ isoforms and the TGF- $\beta$ type RII proved to be the most responsive elements within the glomerulus and tubules in response to diabetes induction [88]. Although concentrations of TGF- $\beta 1$ protein decreased in the glomerulus, increased concentrations could be detected in the tubules by immunohistochemistry [88]. This observation along with the TGF- $\beta 1$ mRNA and TGF- $\beta 1$ protein concentrations in cortical homogenates being increased in diabetes, indicates a pronounced compartmentalization of the changes in TGF- $\beta 1$ in diabetes. By contrast to the changes in glomerular TGF- $\beta 1$ concentrations, the glomerular TGF- $\beta 2$ isoform concentrations increased statistically significantly in response to induction of diabetes [88]. Of further note the spatio-temporal rise in TGF- $\beta 2$ corresponded exactly with that of pro-collagen-1C peptide, a marker of renal fibrosis [88]. Concentrations of glomerular TGF- $\beta$ type RII protein were also considerably increased during development of diabetes [88]. This observation is of note because the TGF- $\beta$ type RII is a necessary receptor for signalling the fibrogenic response to the nucleus as described above [84] (Fig.5). It seems that glomerular TGF- $\beta$ type RII is coordinately upregulated with the glomerular TGF- $\beta 2$ isoform in diabetes, suggesting that fibrogenic signalling is up-regulated, which could result in the increased rate of fibrosis observed in the diabetic kidney. These experimental studies support the hypothesis that the glucose-induced rise in renal TGF- $\beta$ expression and peptide in the kidney are responsible for some of the renal changes that precede the development of diabetic nephropathy.

Agents with effects on the altered TGF- $\beta$ axis in diabetic kidney disease

Agents that have been shown to affect the TGF- $\beta$ axis and exert beneficial renal effects in diabetic kidney disease in experimental animal models are given in Table 2. Each agent is discussed in detail below.

Neutralizing antibodies. Data supporting the hypothesis that the glucose-induced rise in renal TGF- $\beta$ expression and peptide is responsible for some of the renal changes that follow the development of diabetic nephropathy have been published in studies using neutralizing antibodies. In vitro the glucose-mediated increase in type IV collagen synthesis in mesangial 
cells is dependent on the autocrine action of TGF- $\beta 1$ because neutralizing antibodies to TGF- $\beta$ attenuate the rise [101]. Further, in vivo treatment of STZ-diabetic mice for 9 days with a neutralizing TGF- $\beta 1$, TGF- $\beta 2$, TGF- $\beta 3$ antibody attenuated the increased renal TGF- $\beta 1$ and TGF- $\beta$ type IIR mRNA expressions and reduced the diabetes-associated renal/ glomerular growth and enhanced renal expression of collagen IV and fibronectin [102].

Angiotensin converting enzyme (ACE) inhibition. It has been suggested that activation of the renal TGF$\beta$ system in diabetes is mediated through, apart from a direct stimulatory effect of hyperglycaemia itself, an activation of the renin-angiotensin system because exposure of mesangial cells in vitro to angiotensin II stimulates the expression of TGF- $\beta$ and extracellular matrix proteins [103]. Further a recent study examined the effect of an ACEi (captopril) on changes induced by high glucose concentrations in the TGF- $\beta$ system and growth in LLC-PK 1 cells, a porcine kidney cell line analogous to the proximal tubule cell [104]. In this cell system high-glucose concentrations increased TGF- $\beta 1$ mRNA, TGF- $\beta$ Type IR and IIR protein expressions and cellular hypertrophy whereas cellular mitogenesis was inhibited. Captopril dosedependently decreased TGF- $\beta$ Type IR and IIR protein expressions and cellular hypertrophy, increased cellular hyperplasia but TGF- $\beta$ mRNA was unchanged [104]. Another study examined the effects of ACE inhibition (ramipril) in vivo in diabetic rats but looked only at changes in TGF- $\beta 1 \mathrm{mRNA}$ and protein in the renal tubulointerstitium and not at possible changes in the glomeruli [105]. Using different techniques it was shown that the diabetes-associated tubular-interstitial increase in TGF- $\beta 1$ and collagen IV (both mRNA and protein) was prevented by ACE inhibition. A recent study from our group aimed at examining the possible effect of ACE-inhibition on the intra-renal (in particular the glomerular) changes in all TGF- $\beta$ isoforms (TGF- $\beta 1$, TGF$\beta 2$, TGF- $\beta 3$ ) and TGF- $\beta$ receptors (type I, type II, type III) in experimental diabetes [106]. Streptozotocin-diabetic and non-diabetic rats were treated for up to 4 weeks with enalapril or placebo. Enalapril partially prevented the diabetes associated renal hypertrophy and fully prevented the increase in AER. Further, enalapril treatment decreased the glomerular concentrations of TGF- $\beta$ type IR and TGF- $\beta$ type IIIR isoforms to values below those of non-diabetic control and decreased the glomerular TGF- $\beta$ type IIR to almost undetectable concentrations. The glomerular expression of the TGF- $\beta$ isoforms were not greatly influenced by treatment [106]. These findings suggest that the TGF- $\beta$ axis operating through a complex intra-renal system, are a statistically significant mediator of the renal changes observed in experimental diabetes. Moreover, ACE inhibition has pro- nounced inhibitory effects on the increased concentrations of the TGF- $\beta$ receptors required for intracellular signalling through this growth factor system (Fig.5). These experimental findings suggest a possible new mechanism of action for ACEi through regulation of a pathophysiologically enhanced circulating and renal TGF- $\beta$ system.

Protein kinase $C(P K C) \beta$ inhibition. Hyperglycaemia-induced activation of PKC and diacylglycerol (DAG) has been suggested to be an important mechanism in the endothelial dysfunction and long-term vascular complications in diabetes [107]. Based on in vitro experiments, it has been proposed that PKC activation in glomerular cells induced by high glucose concentrations is followed by increased TGF- $\beta$ activity [108] and mitogen-activated protein (MAP) kinase activity [109]. In a recent study, treating mesangial cells exposed to high glucose concentrations with antioxidant alfa-tocopherol blocked the increase in PKC, TGF- $\beta$ and matrix accumulation but did not alter the effect of TGF- $\beta$-induced matrix production [108]. In vivo experiments in which a specific PKC $\beta$ isoform inhibitor (LY 333531) was given to STZ-diabetic rats for 3 months the diabetes-associated increase in glomerular TGF- $\beta 1$ mRNA, matrix accumulation and vascular dysfunctions [i.e. increased glomerular filtration rate (GFR) and AER], were abolished suggesting that hyperglycaemia-induced $\mathrm{PKC} \beta$ activation is involved in the mediation of abnormal glomerular and mesangial functions, such as overproduction of TGF- $\beta$ and matrix components $[110,111]$. Further, in a recent long-term study in diabetic $d b / d b$ mice (an experimental model of Type II (non-insulin-dependent) diabetes mellitus), PKC $\beta$ inhibition reduced long-term renal changes, including mesangial expansion [112]. Glomerular TGF- $\beta 1$ immunostaining was increased in placebo-treated $d b /$ $d b$ mice and partly restored to normal in mice treated with $\mathrm{PKC} \beta$ inhibitor [112]. In a recent study treating STZ-diabetic rats for 1 month with the same specific $\mathrm{PKC} \beta$ isoform inhibitor (LY 333531) showed, however, renoprotective effects, without effect on any components of the intra-renal TGF- $\beta$ system [113]. In contrast to other studies $[110,112]$, this study included a full characterization of changes in all TGF- $\beta$ isoforms and receptors, thus indicating that the renoprotective effects of $\mathrm{PKC} \beta$ inhibition in vivo might not strictly be mediated through the TGF- $\beta$ system.

Advanced glycation end-product (AGE) inhibition. Inan experimental model of Type II diabetes [the Otsuka-Long-Evans-Tokushima Fatty (OLETF) rat] renal TGF- $\beta 1$ mRNA and glomerular TGF- $\beta 1$ immunoreactivity was reported to be increased over a diabetes duration of 9 to 68 weeks [114]. Oral treatment with a new AGE-inhibitor (OPB-9195) for up to 68 weeks reduced the increased renal expressions of 
TGF- $\beta 1$ mRNA and concentrations of protein to normal, along with restoring diabetes-associated renal collagen IV accumulation to normal and diminishing the increased AER [114].

\section{Vascular endothelial growth factor (VEGF)}

\section{The VEGF system}

The group of VEGFs consists of at least five different isoforms of homodimeric glycoproteins [115-122]. Further, at least two high-affinity VEGF receptors, (VEGFR-1) and VEGFR-2, have been described [118]. Vascular endothelial growth factor is a 46000 $\mathrm{M}_{\mathrm{r}}$ homodimeric glycoprotein with pronounced angiogenic actions [116, 119-121] and effects on vascular permeability $[115,119,124]$. The expression of VEGF was initially described to be considerably increased in highly vascularized, rapidly growing tumours [123] and VEGF has been shown to be a potent mitogenic factor for endothelial cells [121, 122]. The two best described VEGF receptors (VEGFR-1 and VEGFR-2), also known as the fms-like tyrosine kinase (Flt) and fetal liver kinase 1 (Flk-1), are highaffinity transmembrane, tyrosine kinase receptors [118]. The VEGFs and their receptors are crucial for embryologic development because disruption of the VEGF system, as seen in KO animals, is lethal [125, 126].

\section{Expression of VEGF system in the normal kidney}

Both VEGF and the two VEGFRs are expressed in the kidney [127-133]. Vascular endothelial growth factor expression and specific VEGF binding has been described in rat [127] and human kidney [128-131]. It has been localized to the epithelial glomerular cells $[131,132]$, the podocytes $[132,133]$ distal tubules and renal collecting ducts [129, 132]. Further, the VEGFR-2 has been localized mainly to the glomerular endothelial cells and cortical interstitial fibroblasts [132].

\section{In vitro evidence for VEGF effects on kidney cells}

In vitro mesangial cells, glomerular endothelial cells, vascular smooth muscle cells, proximal and distal tubular cells are capable of producing VEGF [133-135]. The most potent stimulator of VEGF that has been found is hypoxia $[124,136]$ but in mesangial cells angiotensin II has been shown to stimulate VEGF, a process that is blocked by co-incubation of losartan, an angiotensin 1 receptor antagonist [133-135]. High glucose concentration has been shown to stimulate VEGF expression in vascular smooth muscle cells [137], probably through PKC stimulation [138]. In addition, phorbol esters stimulate mesangial VEGF production [139] and notably, inhibition of PKC blocks VEGF signalling [140]. Further, various growth factors and cytokines, including TGF- $\beta$ [141, 142], IGF-I [143], basic fibroblastic growth factor (bFGF) [144] and platelet derived growth factor (PDGF) [136, 145] have been shown to stimulate VEGF production in various non-renal cell types. Finally, as mentioned above, both IGF-I [79] and VEGF [80] stimulate NF- $x$ B concentrations in endothelial cells in vitro.

\section{In vivo evidence for a role of the VEGF system in diabetic kidney disease}

In the recent study in OLETF rats described above [114], renal VEGF mRNA and glomerular VEGF immunoreactivity was reported to be increased over a diabetes duration of 9 to 68 weeks [114]. In another purely descriptive study, changes in renal VEGF concentrations were described in STZ-diabetic rats with a diabetes duration of 3 and 32 weeks [132]. Vascular endothelial growth factor mRNA and protein were localized mainly to the glomerular epithelial cells and VEGFR-2 mRNA mainly to glomerular endothelial cells [132]. Vascular endothelial growth factor mRNA and peptide were increased in diabetic animals at both time-points examined but the expression of VEGFR-2 and VEGF receptor binding were increased at 3 weeks only [132].

Agents with effect on the altered VEGF axis in diabetic kidney disease

Although the area of identifying and developing specific antagonists of a pathophysiologically enhanced VEGF system in oncology and different eye diseases has attracted increasing interest in the last few years [146], only a few studies have been published on the effect of VEGF antagonists in diabetic kidney disease. These studies are described in detail below along with some promising new candidates.

Neutralizing antibodies. Data supportive for the hypothesis that an enhanced renal VEGF system is responsible for the diabetes-associated renal changes, have been published in a study using an anti-VEGF monoclonal neutralizing antibody in STZ-diabetic rats [147]. Treatment for 6 weeks with the VEGF antibody fully abolished the diabetes-associated hyperfiltration and partially abolished the increase in AER [147]. Treatment with VEGF antibody had no effect on metabolic control in diabetic animals and no renal effects of treatment were seen in non-diabetic controls [147]. 
Advanced glycation end-product (AGE) inhibition. In the study described above in an animal model of Type II diabetes [114], it was shown that long-term AGEinhibitor (OPB-9195) treatment of diabetic animals abolished the enhanced renal VEGF mRNA and glomerular VEGF immunoreactivity along with renoprotection, by restoring diabetes-induced renal collagen IV accumulation to normal and reducing the rise in AER [114].

Other potential treatments. Although not proved, several of the available agents that have beneficial renal effects in diabetic animal models could turn out in the near future to involve VEGF as a downstream cytokine. As mentioned above VEGF has been shown to be stimulated by IGF-I [143] and further, IGF-IR blockade in an ischaemia-induced retinopathy model has been shown to lower enhanced retinal VEGF expression along with reducing retinal neovascularization [78]. In addition, blockade of $\mathrm{PKC} \beta$ activity with a specific inhibitor (LY333531) suppresses the VEGF-induced alterations in retinal leakage, retinal blood flow and ischaemia-induced retinal neovascularization [148-150]. Future studies are warranted to fully explain the role of VEGF as a downstream mediator for some of the pathways leading to diabetic renal damage.

\section{Epidermal growth factor (EGF)}

\section{The EGF system}

The EGF family is a group of peptide growth factor ligands and receptors which is being expanded by continuing studies [151-153]. At present the EGF family comprises four receptors, the EGF receptor (EGFr), erb-B2, erb-B3 and erb-B4 [153]. These receptors are activated by EGF ligand binding followed by homodimerisation and heterodimerisation of the receptors [153]. The EGFr, which is a transmembrane thyrosine kinase receptor, is the most explored receptor of the EGF family and it has been shown that other than activation by EGF, the EGFr is also stimulated by other related ligands such as transforming growth factor $\alpha$, heparin-binding EGF, amphiregulin, betaregulin and epiregulin.

\section{Expression of the EGF system in the normal kidney}

The kidney is one of the main sites of EGF synthesis and several studies have suggested that the kidney is also a target organ for ligands of the EGF family [154]. Epidermal growth factor receptors are present in mesangial cells, in medullary interstitial cells and in the basolateral cell membrane of proximal tubular cells and in the collecting ducts [155-159]. Epidermal growth factor is produced in the thick ascending limb of Henles and in the distal tubules and accordingly it is unlikely that EGF itself stimulates the renal EGFr. It is therefore believed that it is not EGF but the other ligands of the EGF family, produced locally in the kidney, which are responsible for stimulation of the EGFr.

\section{In vitro evidence for EGF effects on kidney cells}

In cell culture systems EGF has been shown to stimulate proliferation of renal tubular cells, with a possible effect through the pentose phosphate pathway and the $\mathrm{Na}^{+} / \mathrm{H}^{+}$antiporter $[157,160]$. Further, EGF has been shown to stimulate phosphorylation and to inhibit gluconeogenesis in rat proximal tubule cells [159]. Finally, the EGF-induced mitogenesis in proximal tubular cells is enhanced by angiotensin II [161], thereby suggesting a possible interaction between the EGF and the renin angiotensin systems.

\section{In vivo evidence for a role of EGF in diabetic kidney disease}

In vivo treatment with EGF systemically or directly into the renal artery increases urine flow and urinary sodium and potassium excretion [162]. The finding that EGF has short-term effects on renal function $[163,164]$ opens some possibilities for a physiological role of EGF in the kidney. Although one study [148] reported reduced urinary EGF excretion after reduction of renal mass, others reported increased urinary EGF excretion [165], increased renal EGF synthesis and a transiently increased amount of immunoreactive EGF in distal kidney tubules after unilateral nephrectomy [166]. In experimental diabetes a possible role for EGF in the early renal enlargement has been proposed. In one study [167] a pronounced increase in diurnal urine EGF excretion was seen but no statistically significant change in renal EGF within the first 7 days after induction of diabetes. These findings were confirmed in a recent study [168] where unchanged concentrations of kidney and plasma EGF were reported, within the first week after induction of diabetes, along with a threefold increase in urinary EGF excretion. In addition, renal EGF mRNA as measured both by northern blotting and in situ hybridization, was increased by $4-8$ times $[168,169]$. After a diabetes duration of 2-3 weeks the urinary EGF excretion was restored to normal or even tended to reach subnormal levels compared with non-diabetic animals $[169,170]$. These studies implicate that EGF plays a part as a renotropic factor in early experimental diabetes. So far no studies have been published on changes in the renal EGF content or EGF excretion in long-term experimental diabetes. 
Agents with effects on the altered EGF axis in diabetic kidney disease

As is the case for VEGF only few studies have been published on pharmacological manipulation of the altered EGF axis in diabetic kidney disease. No specific EGF inhibitors have been designed. Some antihypertensive drugs have, however, proved effects on the EGF production or excretion or both in experimental diabetes as indicated below.

Adrenergic blockade. In a recent study in experimental diabetes the effect of $\alpha$-adrenergic blockade (prazosin), $\beta$-adrenergic blockade (propranolol) or combined treatment was examined in STZ-diabetic rats [170]. Treatment with prazosin or propranolol alone or both drugs in combination, reduced diabetic renal hypertrophy, the rise in renal EGF content and the rise in urinary EGF excretion to the same extent, without altering metabolic control of the diabetic animals [170]. These results seem to indicate a newly discovered relation between the sympathetic nervous system, EGF and early renal enlargement in diabetes.

\section{Conclusions}

Despite beneficial effects of intensified metabolic control, early treatment with ACEi in microalbuminuric Type I diabetic patients and intensified antihypertensive treatment in Type II diabetic patients, the development of diabetic nephropathy is still a huge clinical problem. The pathogenesis of diabetic kidney disease is believed to be multifactorial and various pathophysiological mechanisms have been suggested, apart from the well-known effects of hyperglycaemia and hypertension themselves. This article has reviewed recent evidence of the importance of growth factors and cytokines in the development of diabetic kidney disease. The knowledge we have today indicates that growth factors and cytokines, through complex endocrine and paracrine systems could be responsible for early and late renal changes in experimental and human diabetes in the absence of sufficient insulin action. Insight into the regulation of growth factors and cytokines in diabetic kidney disease have allowed specific antagonists of these systems to be developed and recent studies have shown that treating with such antagonists in experimental diabetes models is followed by renoprotection. Notable observations in recent years are that there is most likely an important interaction or cross-talk among various growth factors that could promote the development of diabetic kidney disease and that combined inhibition of several of these potential pathogenic pathways towards the development of diabetic kidney disease could be more efficient than application of a single antagonism. This would imply that strate- gies which involve multiple effects on the development of diabetic kidney disease could be more effective than drugs which influence one pathway. The combination of inhibitors with different points of action have the potential to provide new therapeutic strategies in the treatment of diabetic kidney disease.

Acknowledgements. The work was supported by the Danish Medical Research Council (Grant No 9700592), the Frænkel Memorial Foundation, the Danish Kidney Foundation, the Ruth König Petersen Foundation, the Danish Diabetes Association, the Novo Foundation, the Nordic Insulin Foundation, the Johanne and Aage Louis Petersen Foundation, the Institute of Experimental Clinical Research, University of Aarhus, Denmark and the Aarhus University-Novo Nordisk Centre for Research in Growth and Regeneration (Danish Medical Research Council Grant No 9600822).

\section{References}

1. Deckert T, Poulsen JE, Larsfin M (1978) Prognosis of diabetics with diabetes onset before age thirty one. Diabetologia 14: 363-370

2. Viberty GC, Hill RD, Jarrett RJ, Argyropoulos A, Mahmud U, Keen H (1982) Microalbuminuria as a predictor of clinical nephropathy in insulin-dependent diabetes mellitus. Lancet: 1430-1432

3. Mogensen E, Christensen CK (1984) Predicting diabetic nephropathy in insulin dependent diabetes mellitus. N Engl J Med 311: 89-93

4. Diabetes Control and Complications Trial Research Group (1993) The effect of intensive treatment of diabetes on the development and progression of long-term complications in insulin-dependent diabetes mellitus. N Engl J Med 329: 977-986

5. United Kingdom Prospective Diabetes Study (UKPDS) Group (1998) Intensive blood-glucose control with sulphonylureas or insulin compared with conventional treatment and risk of complications in patients with type 2 diabetes (UKPDS 33). Lancet 352: 837-853

6. McNeill JH (ed) (1999) Experimental models of diabetes. CRC Press LLC, Boca Raton, Florida, USA, pp. 1-418

7. Young FG (1937) Permanent diabetes produced by pituitary (anterior lobe) injections. Lancet : 372-374

8. Campbell J, Davidson IWF, Lei HP (1950) The production of permanent diabetes by highly purified growth hormone. Endocrinology 46: 588-590

9. Yde H (1969) Abnormal growth hormone response to ingestion of glucose in juvenile diabetics. Acta Med Scand 186: 499-504

10. Hansen AP, Johansen K (1970) Diurnal pattern of blood glucose, serum FFA, insulin, glucagon and growth hormone in normals and juvenile diabetics. Diabetologia 6: 27-33

11. Lundbæk K, Christensen HJ, Jensen VA et al. (1970) Diabetes, diabetic angiopathy and growth hormone (hypothesis). Lancet: 131-133

12. Yde H (1969) The growth hormone dependent sulphation factor in serum from patients with various types of diabetes. Acta Med Scand 186: 293-297

13. Flyvbjerg A (1990) Growth factors and diabetic complications. Diabetic Med 7: 387-399

14. Janssen JAMJL, Lamberts SWJ (2000) Circulating IGF-I and its protective role in the pathogenesis of diabetic angiopathy. Clin Endocrinol (Oxf) 52: 1-9 
15. Carlsson B, Billig H, Rymo L, Isakson OGP (1990) Expression of the growth hormone binding protein messenger RNA in the liver and extra-hepatic tissues in the rat; co-expression with the growth hormone receptor. Mol Cell Endocrinol 73: R1-R6

16. Landau D, Domene H, Flyvbjerg A et al. (1998) Differential expression of renal growth hormone receptor and its binding protein in experimental diabetes mellitus. $\mathrm{GH}$ and IGF Research 8: 39-45

17. Pillion DJ, Haskell JF, Meezan E (1988) Distinct receptors for insulin-like growth factor I in rat renal glomeruli and tubules. Am J Physiol 255: E504-E512

18. Werner H, Shen-Orr Z, Stannard B, Burguera B, Roberts Jr CT, LeRoith D (1990) Experimental diabetes increases insulin-like growth factor I and II receptor concentration and gene expression in kidney. Diabetes 39: 1490-1497

19. Flyvbjerg A, Nielsen S, Sheikh MI, Jacobsen C, Ørskov H, Christensen EI (1993) Luminal and basolateral uptake and receptor binding of IGF-I in rabbit renal proximal tubules. Am J Physiol 43: 796-807

20. Shimasaki S, Shimonaka M, Zhang HP, Ling N (1991) Identification of five different IGFBPs from adult rat serum and molecular cloning of a novel IGFBP-5 in rat and human. J Biol Chem 266: 10646-10653

21. Shimasaki S, Gao L, Shimonaka M, Ling N (1991) Isolation and molecular cloning of IGFBP-6. Mol Endocrinol 4: 1451-1458

22. Hwa V, Oh Y, Rosenfeld R (1999) The insulin-like growth factor binding protein (IGFBP) superfamily. Endocr Rev 20: 761-787

23. Bortz JD, Rotwein P, DeVol D, Bechtel PJ, Hansen VA, Hammerman MR (1988) Focal expression of insulin-like growth factor I in rat kidney collecting duct. J Cell Biol 107: 811-819

24. Flyvbjerg A, Bornfeldt KE, Marshall SM, Arnqvist HJ, Ørskov H (1990) Kidney IGF-I mRNA in initial renal hypertrophy in experimental diabetes in rats. Diabetologia 33: 334-338

25. Murphy LJ, Bell GI, Frisen HG (1987) Tissue distribution of insulin-like growth factor I and II ribonucleic acid in the adult rat. Endocrinology 120: 1279-1282

26. Landau D, Chin E, Bondy C et al. (1995) Expression of insulin-like growth factor binding proteins in the rat kidney: Effects of long-term diabetes. Endocrinology 136: 1835-1842

27. Flyvbjerg A, Ørskov H, Alberti KGMM (eds) (1993) Growth hormone and insulin-like growth factor I in human and experimental diabetes. John Wiley \& Sons, Chichester New York Brisbane Toronto Singapore, pp. 1-322

28. Flyvbjerg A, Alberti KGMM, Froesch ER, de Meyts P, von zür Mühlen A, Ørskov H (eds) (1995) International symposium on glucose metabolism and growth factors. Metabolism 44: 1-123

29. Conti FG, Striker LJ, Lesniak MA, MacKay K, Roth J, Striker GE (1988) Studies on binding and mitogenic effect of insulin and insulin-like growth factor I in glomerular mesangial cells. Endocrinology 122: 2788-2795

30. Doi T, Striker LJ, Elliot S, Conti FG, Agodoa L, Striker GE (1989) Insulin-like growth factor I is a progression factor for human mesangial cells. Am J Pathol 134: 395-404

31. Moran A, Brown DM, Kim Y, Klein DJ (1991) Effects of IGF-I and glucose on protein and proteoglycan synthesis by human fetal mesangial cells in culture. Diabetes 40 : 1346-1354

32. Bar RS, Dake BL, Stueck S (1987) Stimulation of proteoglycan by IGF-I and -II in microvessel and large vessel endothelial cells. Am J Physiol 253: E21-E27
33. Elliot SJ, Striker LJ, Hattori M et al. (1993) Mesangial cells from diabetic NOD mice constitutively secrete increased amounts of insulin-like growth factor I. Endocrinology 133: 1783-1788

34. Lupia E, Elliot SJ, Lenz O et al. (1999) IGF-I decreases collagen degradation in diabetic NOD mesangial cells: implications for diabetic nephropathy. Diabetes 48: 1638-1644

35. Tannenbaum GS (1981) Growth hormone secretion dynamics in streptozotocin diabetes: Evidence of a role for endogenous somatostatin. Endocrinology 108: 76-82

36. Marshall SM, Alberti KGMM (1993) Alterations in the growth hormone/insulin-like growth factor axis in human and experimental diabetes: differences and similarities. In: Flyvbjerg A, Ørskov H, Alberti KGMM (eds) Growth hormone and insulin-like growth factor I in human and experimental diabetes. John Wiley \& Sons, Chichester, pp. 23-46

37. Flyvbjerg A, Bennett WF, Rasch R, Kopchick JJ, Scarlett JA (1999) Inhibitory effect of a growth hormone receptor antagonist (G120K-PEG) on renal enlargement, glomerular hypertrophy and urinary albumin excretion in experimental diabetes in mice. Diabetes 48: 377-382

38. Massa G, Verhaeghe J, Vanderschueren-Lodeweyckx M, Boulillon R (1993) Normalization of decreased plasma concentrations of growth hormone-binding protein by insulin treatment in spontaneously diabetic BB rats. Horm Metab Res 25: 325-326

39. Maes M, Ketelslegers J-M, Underwood LE (1983) Low plasma somatomedin-C in streptozotocin-induced diabetes mellitus. Correlation with changes in somatogenic and lactogenic liver binding sites. Diabetes 32: 1060-1069

40. Flyvbjerg A (1993) The role of insulin-like growth factor I in intial renal hypertrophy in experimental diabetes. In: Flyvbjerg A, Ørskov H, Alberti KGMM (eds) Growth hormone and insulin-like growth factor I in human and experimental diabetes. John Wiley \& Sons, Chichester, pp. 271-306

41. Bornfeldt KE, Arnqvist HJ, Enberg B, Mathews LS, Norstedt G (1989) Regulation of insulin-like growth factor I and growth hormone receptor gene expression by diabetes and nutritional state in rat tissues. J Endocrinol 122: 651-656

42. Flyvbjerg A, Frystyk J, Østerby R, Ørskov H (1992) Kidney IGF-I and renal hypertrophy in GH deficient dwarf rats. Am J Physiol 262: E956-E962

43. Flyvbjerg A, Thorlacius-Ussing O, Næraa R, Ingerslev J, Ørskov H (1988) Kidney tissue somatomedin C and initial renal growth in diabetic and uninephrectomized rats. Diabetologia 31: 310-314

44. Flyvbjerg A, Frystyk J, Thorlacius-Ussing O, Ørskov H (1989) Somatostatin analogue administration prevents increase in kidney somatomedin $\mathrm{C}$ and initial renal growth in diabetic and uninephrectomized rats. Diabetologia 32: 261-265

45. Bach LA, Jerums G (1990) Effect of puberty on initial kidney growth and rise in kidney IGF-I in diabetic rats. Diabetes 39: 557-562

46. Bach LA, Cox AJ, Mendelsohn FAO, Werther G, Jerums $G$ (1992) Focal induction of IGF-binding proteins in the proximal tubules of diabetic rat kidney. Diabetes 41: 499-507

47. Flyvbjerg A, Ørskov H (1990) Kidney tissue insulin-like growth factor I and initial renal growth in diabetic rats: Relation to severity of diabetes. Acta Endocrinol (Copenh) 122: 374-378 
48. Segev Y, Landau D, Marbach M, Schadeh N, Flyvbjerg A, Phillip M (1997) Renal hypertrophy in hyperglycemic nonobese diabetic (NOD) mice is associated with persistent renal accumulation of insulin-like growth factor (IGF) I. J Am Soc Nephrol 8: 436-444

49. Flyvbjerg A, Bornfeldt KE, Ørskov H, Arnqvist HJ (1991) Effect of insulin-like growth factor I infusion on renal hypertrophy in experimental diabetes mellitus in rats. Diabetologia 34: 715-720

50. Charlton HM, Clark RG, Robinson ICAF et al. (1988) Growth hormone-deficient dwarfism in the rat: a new mutation. J Endocrinol 119: 51-58

51. Grønbæk H, Volmers P, Bjørn SF, Østerby R, Ørskov H, Flyvbjerg A (1997) Effect of isolated GH and IGF-I deficiency on long-term renal changes and urinary albumin excretion in streptozotocin diabetic dwarf rats. Am J Physiol 272: E918-E924

52. Bach LA, Stevenson JL, Allen TJ, Jerums G, Herington AD (1991) Kidney insulin-like growth factor I mRNA levels are increased in postpubertal diabetic rats. $\mathrm{J}$ Endocrinol 129: 5-10

53. Weiss O, Anner H, Nephesh I, Alayoff A, Burstyn M, Raz I (1995) Insulin-like growth factor I (IGF-I) and IGF-I receptor gene expression in the kidney of chronically hypoinsulinemic rat and hyperinsulinemic rat. Metabolism 44: 982-986

54. Marshall SM, Flyvbjerg A, Frystyk J, Korsgaard L, Ørskov H (1991) Renal insulin-like growth factor I and growth hormone receptor binding in experimental diabetes and after unilateral nephrectomy in the rat. Diabetologia 34: 632-639

55. Flyvbjerg A, Kessler U, Kiess W (1994) Increased kidney and liver insulin-like growth factor II/Mannose-6-phosphate receptor concentration in experimental diabetes in rats. Growth Regul 4: 188-193

56. Flyvbjerg A, Kessler U, Dorka B, Funk B, Ørskov H, Kiess W (1992) Transient increase in renal IGF binding proteins during initial kidney hypertrophy in experimental diabetes in rats. Diabetologia 35: 589-593

57. Grønbæk H, Nielsen B, Frystyk J, Flyvbjerg A, Ørskov H (1996) Effect of lanreotide, a somatostatin analogue, on diabetic renal hypertrophy, kidney and serum IGF-I and IGF binding proteins. Exp Nephrol 4: 295-303

58. Steer KA, Sochor M, Kunjara S, Doepfner W, McLean P (1988) The effect of a somatostatin analogue (SMS 201-995) on the concentration of phosphoribosyl pyrophosphate and the activity of the pentose phosphate pathway in the early renal hypertrophy of experimental diabetes in the rat. Biochem Med Metab Biol 39: 226-233

59. Grønbæk H, Nielsen B, Frystyk J, Ørskov H, Flyvbjerg A (1995) Effect of octreotide on experimental diabetic renal and glomerular growth: Importance of early intervention. J Endocrinol 147: 95-102

60. Grønbæk H, Nielsen B, Østerby R, Harris AG, Ørskov H, Flyvbjerg A (1995) Effect of octreotide and insulin on manifest renal and glomerular hypertrophy and urinary albumin excretion in long-term experimental diabetes in rats. Diabetologia 38: 135-144

61. Raz I, Rubinger D, Popovtzer M, Grønbæk H, Weiss O, Flyvbjerg A (1998) Octreotide prevents the early increase in renal insulin-like growth factor binding protein 1 in streptozotocin diabetic rats. Diabetes 47: 924-930

62. Flyvbjerg A, Schuller AGP, van Neck JW, Groffen C, Ørskov H, Drop SLS (1995) Stimulation of hepatic insulinlike growth factor binding protein-1 and -3 gene expression by octreotide in rats. J Endocrinol 147: 545-551
63. Flyvbjerg A, Marshall SM, Frystyk J, Hansen KW, Harris AG, Ørskov H (1992) Octreotide administration in diabetic rats: effects on renal hypertrophy and urinary albumin excretion. Kidney Int 41: 805-812

64. Muntzel M, Hannedouche T, Niesor R et al. (1992) Longterm effects of a somatostatin analogue on renal haemodynamics and hypertrophy in diabetic rats. Clin Sci (Colch) 83: 575-581

65. Igarashi K, Ito S, Shibata A (1990) Effect of a somatostatin analogue (SMS 201-995) on urinary albumin excretion in streptozotocin-induced diabetic rats. J Japan Diab Soc 33: $531-538$

66. Igarashi K, Nakazawa A, Tani N, Yamazaki M, Ito S, Shibata A (1991) Effect of a somatostatin analogue (SMS 201-995) on renal function and excretion in diabetic rats. J Diabetes Complications 5: 181-183

67. Grønbæk H, Vogel I, Lancranjan I, Flyvbjerg A, Ørskov H (1998) Effect of octreotide, captopril, or insulin on manifest long-term experimental diabetic renal changes. Kidney Int 53: 173-180

68. Chen WY, Wight DC, Wagner TE, Kopchick JJ (1990) Expression of a mutated bovine growth hormone gene suppresses growth of transgenic mice. Proc Natl Acad Sci USA 87: 5061-5065

69. Chen WY, White ME, Wagner TE, Kopchick JJ (1991) Functional antagonism between endogenous mouse growth hormone $(\mathrm{GH})$ and a $\mathrm{GH}$ analog results in dwarf transgenic mice. Endocrinology 129: 1402-1408

70. Chen N-Y, Chen WY, Bellush L et al. (1995) Effects of streptozotocin treatment in growth hormone $(\mathrm{GH})$ and $\mathrm{GH}$ antagonist transgenic mice. Endocrinology 136: 660-667

71. Chen N-Y, Chen WY, Kopchick JJ (1996) A growth hormone antagonist protects mice against streptozotocin induced glomerulosclerosis even in the presence of elevated levels of glucose and glycated hemoglobin. Endocrinology 137: 5163-5165

72. Bellush LL, Doublier S, Holland AN, Striker LJ, Striker GE, Kopchick JJ (2000) Protection against diabetes-induced nephropathy in growth hormone receptor/binding protein gene-disrupted mice. Endocrinology 141: 163-168

73. Segev Y, Landau D, Rasch R, Flyvbjerg A, Phillip M (1999) Growth hormone receptor antagonism prevents early renal changes in nonobese diabetic mice. J Am Soc Nephrol 10: 2374-2381

74. Flyvbjerg A, Rasch R (1999) Effect of growth hormone $(\mathrm{GH})$ receptor antagonist $(\mathrm{G} 120 \mathrm{~K}-\mathrm{PEG})$ treatment on manifest renal changes in non obese diabetic (NOD) mice [Abstract]. J Am Soc Nephrol 10: A3443

75. Pietrzkowski A, Wernicke D, Porcu P, Jameson BA, Baserga R (1992) Inhibition of cell proliferation by peptide analogues of insulin-like growth factor I. Cancer Res 52: 6447-6451

76. Havry P, Myllarniemi M, Aavik E et al. (1995) Stable Dpeptide analogue of insulin-like growth factor I inhibits smooth muscle cell proliferation after carotid balloning injury in the rat. FASEB J 9: 1336-1344

77. Haylor J, Hickling H, El Eter E et al. (2000) JB3, an IGF-I receptor antagonist, inhibits early renal growth in diabetic and uninephrectomized rats. J Am Soc Nephrol (in press)

78. Smith LE, Shen W, Perruzzi C et al. (1999) Regulation of vascular endothelial growth factor-dependent retinal neovascularization by insulin-like growth factor I receptor. Nature 5: 1390-1395

79. Balaram SK, Agrawal DK, Edwards JD (1999) Insulinlike growth factor I activates nuclear factor- $x \mathrm{~B}$ and in- 
creases transcription of the intercellular adhesion molecule-1 gene in endothelial cells. Cardiovasc Surg 7: 91-97

80. Marumo T, Schini-Kerth VB, Buss R (1999) Vascular endothelial growth factor activates nuclear factor- $x \mathrm{~B}$ and induces monocyte chemoattractant protein-1 in bovine retinal endothelial cells. Diabetes 48: 1131-1137

81. Bach LA, Dean R, Youssef S, Cooper ME (2000) Aminoguanidine ameliorates changes in the IGF system in experimental diabetic nephropathy. Nephrol Dial Transplant 15: 347-354

82. New JP, Canavan JP, Flyvbjerg A, Hamon G, Bilous RW, Marshall SM (1996) Renal enlargement and IGF-I accumulation in experimental diabetes is not prevented by angiotensin converting enzyme inhibition. Diabetologia 39: 166-171

83. Lawrence DA (1995) Transforming growth factor $\beta$ : An overview. Kidney Int 47: S19-S23

84. Wrana JL, Attisano L, Wieser R, Ventura F, Massagué J (1994) Mechanism of activation of the TGF- $\beta$ receptor. Nature 370: 341-347

85. Nakamura T, Fukui M, Ebihara E et al. (1993) mRNA expression of growth factors in glomeruli from diabetic rats. Diabetes 42: 450-456

86. Ziyadeh FN, Chen Y, Davila A, Goldfarb S (1992) Self limited stimulation of mesangial cell growth in high glucose: autocrine activation of TGF- $\beta$ reduces proliferation but increases mesangial matrix. Kidney Int 42: 647-656

87. Choi ME, Eung-Gook K, Ballerman BJ (1993) Rat mesangial cell hypertrophy in response to transforming growth factor $\beta 1$. Kidney Int 44: 948-958

88. Hill C, Flyvbjerg A, Grønbæk H et al. (2000) The renal expression of transforming growth factor $\beta$ isoforms and their receptors in acute and chronic experimental diabetes in rats. Endocrinology 141: 1196-1208

89. Ziyadeh FN, Snipes ER, Watanabe M, Alvarey RJ, Goldfarb S, Haverty TP (1990) High glucose induces cell hypertrophy and stimulates collagen gene transcription in proximal tubule. Am J Physiol 259: F704-F714

90. Nakamura T, Miller D, Rouslahti E, Border WA (1992) Production of extracellular matrix by glomerular epithelial cells is regulated by transforming growth factor $\beta 1$. Kidney Int 41: 1213-1221

91. Humes HD, Nakamura T, Cieslinski DA, Miller D, Emmons RV, Border WA (1993) Role of protoglycans and cytoskeleton in the effects of TGF- $\beta 1$ on renal proximal tubule cells. Kidney Int 43: 575-584

92. Roberts AB, McCune BK, Sporn MB (1992) TGF- $\beta 1$ : Regulation of extracellular matrix. Kidney Int 41: 557-559

93. Davies M, Thomas GJ, Martin J, Lovett DH (1988) The purification and characterisation of a glomerular basement membrane degrading neutral proteinase from the rat mesangial cells. Biochem J 251: 419-425

94. Marti HP, Lee L, Kashgarian M, Lovett DH (1994) Transforming growth factor $\beta 1$ stimulates mesangial cell synthesis of the $72 \mathrm{kD}$ type IV collagenase. Am J Pathol 144: 82-94

95. Okuda S, Languino LR, Ruoslahti E, Border WA (1990) Elevated expression of transforming growth factor- $\beta$ and proteoglycan production in experimental glomerulonephritis. Possible role in expansion of the mesangial matrix. J Clin Invest 86: 453-462

96. Kolm V, Sauer U, Olgemoller B, Schleicher ED (1996) High glucose-induced TGF- $\beta 1$ regulates mesangial production of heparan sulphate proteoglycan. Am J Physiol 70: F812-F821
97. Shankland SJ, Scholey JW (1994) Expression of transforming growth factor $\beta 1$ during diabetic renal hypertrophy. Kidney Int 46: 430-442

98. Sharma K, Ziyadeh FN (1994) Renal hypertrophy is associated with upregulation of TGF- $\beta 1$ gene expression in diabetic BB rat and NOD mouse. Am J Physiol 67: F1094-F1101.

99. Pankewycz OG, Guan J-X, Kline Bolton W, Gomez A, Benedict JF (1994) Renal TGF- $\beta$ regulation in spontaneously diabetic NOD mice with correlations in mesangial cells. Kidney Int 46: 748-758

100. Wogensen L, Nielsen CB, Hjort P et al. (1999) Under control of the Ren-1 c promoter, locally produced transforming growth factor- $\beta 1$ induces accumulation of glomerular extracellular matrix in transgenic mice. Diabetes 48: 182-192

101. Ziyadeh FN, Sharma K, Ricksen N, Wolf G (1994) Stimulation of collagen gene expression and protein synthesis in murine mesangial cells by high glucose is mediated by autocrine activation of transforming growth factor $\beta$. J Clin Invest 93: 536-542

102. Sharma K, Jin Y, Guo J, Ziyadeh FN (1996) Neutralization of TGF- $\beta$ by anti-TGF- $\beta$ antibody attenuates kidney hypertrophy and the enhanced extracellular matrix gene expression in STZ-induced diabetic mice. Diabetes 45: $522-530$

103. Kagami S, Border WA, Miller DE, Noble NA (1994) Angiotensin II stimulates extracellular matrix protein synthesis through induction of transforming growth factor- $\beta$ expression in rat glomerular mesangial cells. J Clin Invest 93: $2431-2437$

104. Guh JY, Yang ML, Yang YL, Chang CC, Chuang LY (1996) Captopril reverses high-glucose-induced growth effects on LLC-PK 1 cells partly by decreasing transforming growth factor- $\beta$ receptor protein expression. J Am Soc Nephrol 7: 1207-1215

105. Gilbert RE, Cox A, Wu LL et al. (1998) Expression of transforming growth factor $\beta 1$ and type IV collagen in the renal tubulointerstitium in experimental diabetes: effects of angiotensin converting enzyme inhibition. Diabetes 47: 414-422

106. Flyvbjerg A, Hill C, Grønbæk H, Logan A (1999) Effect of ACE-inhibition on renal TGF- $\beta$ type II receptor expression in experimental diabetes in rats [Abstract]. J Am Soc Nephrol 10: A3444

107. Koya D, King GL (1998) Protein kinase C activation and the development of diabetic complications. Diabetes 47: 859-866

108. Studer RK, Craven PA, DeRubertis FR (1997) Antioxidant inhibition of protein kinase C-signaled increases in transforming growth factor- $\beta$ in mesangial cells. Metabolism 46: 918-925

109. Haneda M, Kikkawa R, Sugimoto T et al. (1995) Abnormalities in protein kinase $\mathrm{C}$ and MAP kinase cascade in mesangial cells cultured under high glucose conditions. J Diabetes Complications 9: 246-248

110. Koya D, Jirousek MR, Lin Y-W, Ishii H, Kuboki K, King $\mathrm{G}$ (1996) Characterization of protein kinase $\mathrm{C} \beta$ isoform activation on the gene expression of transforming growth factor- $\beta$, extracellular matrix components and prostanoids in the glomeruli of diabetic rats. J Clin Invest 100: $115-126$

111. Ishii H, Jirousek MR, Koya D et al. (1996) Amelioration of vascular dysfunctions in diabetic rats by an oral PKC $\beta$ inhibitor. Science 272: 728-731

112. Koya D, Haneda M, Nakagawa H et al. (2000) Amelioration of accelerated diabetic mesangial expansion by treat- 
ment with a PKC $\beta$ inhibitor in diabetic $\mathrm{db} / \mathrm{db}$ mice, a rodent model for type 2 diabetes. FASEB J 14: 439-447

113. Flyvbjerg A, Hill C, Nielsen B, Logan A (1999) Effect of protein kinase $\mathrm{C} \beta$ inhibition on renal morphology, urinary albumin excretion and renal transforming growth factor $\beta$ in experimental diabetes in rats [Abstract]. J Am Soc Nephrol 10: A3445

114. Tsuchida K, Makita Z, Yamagishi S et al. (1999) Suppression of transforming growth factor $\beta$ and vascular endothelial growth factor in diabetic nephropathy in rats by a novel advanced glycation end product inhibitor, OPB9195. Diabetologia 42: 579-588

115. Senger DR, Galli SJ, Dvorak AM, Perruzzi CA, Harvey VS, Dvorak HF (1983) Tumor cells secrete a vascular permeability factor that promotes accumulation of ascites fluid. Science 219: 983-985

116. Keck PJ, Hauser SD, Krivi G et al. (1989) Vascular permeability factor, an endothelial cell mitogen related to PDGF. Science 246: 1309-1312

117. Tisher E, Mitchell R, Hartman T et al. (1991) The human gene for vascular endothelial growth factor. Multiple protein forms are encoded through alternative exon splicing. J Biol Chem 266: 11947-11954

118. Neufeld G, Cohen T, Gengrinovitch S, Poltorak Z (1999) Vascular endothelial growth factor (VEGF) and its receptors. FASEB J 13: 9-22

119. Senger DR, Connolly DT, van de Water L, Feder J, Dvorak HF (1990) Purification and $\mathrm{NH}_{2}$-terminal amino acid sequence of guinea pig tumor-secreted vascular permeability factor. Cancer Res 50: 1774-1778

120. Leung DW, Cachianes G, Kuang WJ, Goeddel DV, Ferrara N (1989) Vascular endothelial growth factor is a secreted angiogenic mitogen. Science 246: 1306-1309

121. Plate KH, Breier G, Weich HA, Risau W (1992) Vascular endothelial growth factor is a potential tumour angiogenesis factor in humans gliomas in vivo. Nature 359: 845-848

122. Farrara N, Houck KA, Jakeman LB, Winer J, Leung DW (1991) The vascular endothelial growth factor family of polypeptides. J Cell Biochem 47: 211-218

123. Kim KJ, Li B, Winer J et al. (1993) Inhibition of vascular endothelial growth factor-induced angiogenesis suppresses tumour growth in vivo. Nature 362: 841-844

124. Shweiki D, Itin A, Soffer D, Keshet E (1992) Vascular endothelial growth factor induced by hypoxia may mediate hypoxia-initiated angiogenesis. Nature 359: 843-845

125. Cameliet P, Ferreira V, Beier G et al. (1996) Abnormal blood vessel development and lethality in embryos lacking a single VEGF allele. Nature 380: 435-439

126. Ferrara N, Carver-Moore K, Chen H et al. (1996) Heterozygous embryonic lethality induced by targeted inactivation of the VEGF gene. Nature 380: 439-442

127. Jakeman LB, Winer J, Bennett GL, Altar CA, Ferrara N (1992) Binding sites for vascular endothelial growth factor are localized on endothelial cells in adult rat tissues. J Clin Invest 89: 244-253

128. Brown LF, Berse B, Tognazzi K et al. (1992) Vascular permeability factor mRNA and protein expression in human kidney. Kidney Int 42: 1457-1461

129. Simon M, Grone HJ, Johren O et al. (1995) Expression of vascular endothelial growth factor and its receptors in human renal ontogenesis and in adult kidney. Am J Physiol 268: F240-F250

130. Grone HJ, Simon M, Grone EF (1995) Expression of vascular endothelial growth factor in renal vascular disease and renal allografts. J Pathol 177: 259-267

131. Simon M, Rockl W, Hornig C et al. (1998) Receptors of vascular endothelial growth factor/vascular permeability factor (VEGF/VPF) in fetal and adult human kidney: localization and $\left[{ }^{125} \mathrm{I}\right] \mathrm{VEGF}$ binding sites. J Am Soc Nephrol 9: 1044-1044

132. Cooper ME, Vranes D, Youssef S et al. (1999) Increased renal expression of vascular endothelial growth factor (VEGF) and its receptor VEGFR-2 in experimental diabetes. Diabetes 48: 2229-2239

133. Williams B (1998) A potential role for angiotensin II-induced vascular endothelial growth factor expression in the pathogenesis of diabetic nephropathy ?. Miner Electrolyte Metab 24: 400-405

134. Pupilli C, Lasagni L, Romagnani P et al. (1999) Angiotensin II stimulates the synthesis and secretion of vascular permeability factor/vascular endothelial growth factor in human mesangial cells. J Am Soc Nephrol 10: 245-255

135. Gruden G, Thomas S, Burt D et al. (1999) Interaction of angiotensin II and mechanical stretch on vascular endothelial growth factor production by mesangial cells. J Am Soc Nephrol 10: 730-737

136. Stavry GT, Hong Y, Zachary IC et al. (1995) Hypoxia and platelet-derived growth factor-BB synergistically upregulate the expression of vascular endothelial growth factor in vascular smooth muscle cells. FEBS Lett 358: 311-315

137. Natarajan R, Bai W, Lanting L, Gonzales N, Nadler J (1997) Effects of high glucose on vascular endothelial growth factor expression in vascular smooth muscle cells. Am J Physiol 42: H2224-H2231

138. Williams B, Gallacher B, Patel H, Orme C (1997) Glucose-induced protein kinase $\mathrm{C}$ activation regulates vascular permeability factor mRNA expression and peptide production by human smooth miscle cells in vitro. Diabetes 46: 1497-1503

139. Iijima K, Yoshikawa N, Connolly DT, Nakamura H (1993) Human mesangial cells and peripheral blood mononuclear cells produce vascular permeability factor. Kidney Int 44: 959-966

140. Pal S, Claffey KP, Dvorak HF, Mukhopadhyay D (1997) The von Hippel-Lindau gene products inhibits vascular permeability factor/vascular endothelial growth factor expression in renal cell carcinoma by blocking protein kinase C pathways. J Biol Chem 272: 27509-27512

141. Mandriota SJ, Menoud PA, Pepper MS (1996) Transforming growth factor $\beta 1$ downregulates vascular endothelial growth factor receptor $2 / \mathrm{flk}-1$ expression in vascular endothelial cells. J Biol Chem 271: 11500-11505

142. Pertovaara L, Kaipainen A, Mustonen Tet al. (1994) Vascular endothelial growth factor is induced in response to transforming growth factor $\beta$ in fibroblastic and epithelial cells. J Biol Chem 269: 6271-6274

143. Goad DL, Rubin J, Wang H, Tashjian Jr AH, Patterson C (1996) Enhanced expression of vascular endothelial growth factor in human SaOS-2 osteoblast-like cells and murine osteoblasts induced by insulin-like growth factor I. Endocrinology 137: 2262-2268

144. Stavri GT, Zachary IC, Baskerville PA, Martin JF, Erusalimsky JD (1995) Basic fibroblast growth factor upregulates the expression of vascular endothelial growth factor in vascular smooth muscle cells: synergistic interaction with hypoxia. Circulation 92: 11-14

145. Williams B, Quinnbaker A, Gallacher B (1995) Serum and platelet-derived growth factor-induced expression of vascular permeability factor mRNA by human vascular smooth muscle cells in vitro. Clin Sci (Colch) 88: 141-147

146. Duh E, Aiello LP (1999) Vascular endothelial growth factor and diabetes: The agonist versus antagoninst paradox. Diabetes 48: 1899-1906 
147. De Vriese A, Tilton R, Vanholder R (1999) Hyperfiltration and albuminuria in diabetes: Role of vascular endothelial growth factor (VEGF)[Abstract]. J Am Soc Nephrol 10: A3434

148. Tilton RG, Kawamura T, Chang KC et al. (1997) Vascular dysfunction induced by elevated glucose levels in rats is mediated by vascular endothelial growth factor. J Clin Invest 99: 2192-2202

149. Aiello LP, Bursell SE, Clermont A et al. (1997) Vascular endothelial growth factor-induced retinal permeability is mediated by protein kinase $\mathrm{C}$ in vivo and suppressed by an orally effective $\beta$-isoform-selective inhibitor. Diabetes 46: $1473-1480$

150. Danis RP, Bingaman DP, Jirousek M, Yang Y (1998) Inhibition of intraocular neovascularization caused by retinal ischemia in pigs by $\mathrm{PKC} \beta$ inhibition with LY 333531. Invest Ophthalmol Vis Sci 39: 171-179

151. Coussens L, Yang-Feng TL, Liao Y-C et al. (1985) Tyrosine kinase receptor with extensive homology to EGF receptor shares chromosomal location with neu oncogene. Science 230: 1132-1139

152. Prigent SA, Lemoire NR (1992) The type 1 (EGFR-related) family of growth factor receptors and their ligands. Prog Growth Factor Res 4: 1-24

153. Salomon DS, Brandt R, Ciardiello F, Normanno N (1995) Epidermal growth factor related peptides and their receptors in human malignancies. Crit Rev Oncol Hematol 19: 183-232

154. Olsen PS, Nexø E, Poulsen SS, Hansen HF, Kirkegaard P (1984) Renal origin of rat urinary epidermal growth factor. Regul Pept 10: 37-45

155. Gustavson B, Cowley G, Smith JA, Ozanne B (1984) Cellular localization of human epidermal growth factor receptor. Cell Biol Int Rep 8: 649-658

156. Harris RC, Hoover RL, Jacobsen HR, Badr KF (1988) Evidence for glomerular actions of epidermal growth factor in the rat. J Clin Invest 82: 1028-1039

157. Vehaskari VM, Hering-Smith KS, Moskowitz DW, Weiner ID, Hamm LL (1989) Effect of epidermal growth factor on sodium transport in the cortical collecting tubule. Am J Physiol 256: F803-F809

158. Sack E, Talor Z (1988) High affinity binding sites for epidermal growth factor (EGF) in renal membranes. Biochem Biophys Res Commun 154: 312-317
159. Harris RC, Daniel TO (1989) Epidermal growth factor binding, stimulation of phosphorylation, and inhibition of glyconeogenesis in rat proximal tubule. J Cell Physiol 139: 383-391

160. Hamm LL, Hering-Smith KS, Vehaskari VM (1993) Epidermal growth factor and the kidney. Semin Nephrol 55: 305-321

161. Norman J, Badie-Dezfooly B, Nord EP et al. (1987) EGFinduced mitogenesis in proximal tubular cells: potentiation by angiotensin II. Am J Physiol 253: F299-F309

162. Scoggins BA, Butkus A, Coghlan JP (1984) In vivo cardiovascular, renal and endocrine effects of epidermal growth factor in sheep. In: Labrie F, Prouix L (eds), Endocrinology, Elsevier Science Publishers B. V., Amsterdam, pp. 573-576

163. Stanton RC, Seifter JL (1988) Epidermal growth factor rapidly activates the hexose monophosphate shunt in kidney cells. Am J Physiol 253: C267-C271

164. Vehaskari VM, Hering-Smith KS, Moskowitz DW, Weirer ID, Hamm LL (1989) Effect of epidermal growth factor on sodium transport in the cortical collecting tubules. Am J Physiol 256: F803-F809

165. Jørgensen PE, Kamper A-L, Munck O, Strandgaard S, Nex $\varnothing$ E (1995) Urinary excretion of epidermal growth factor in living human kidney doners and their recipients. Eur J Clin Invest 25: 442-446

166. Jennische E, Andersson G, Hansson HA (1987) Epidermal growth factor is expressed by cells in the distal tubulus during postnephrectomy renal growth. Acta Physiol Scand 129: 449-450

167. Guh JY, Lai YH, Shin SJ, Chuang LY, Tsai JH (1991) Epidermal growth factor in renal hypertrophy in streptozotocin-diabetic rats. Nephron 59: 641-647

168. Gilbert RE, Cox A, McNally PG et al. (1997) Increased epidermal growth factor in experimental diabetes related renal growth. Diabetologia 40: 778-785

169. Thulesen J, Jørgensen PE, Torffvit O, Nexø E, Poulsen SS (1997) Urinary excretion of epidermal growth factor and Tamm-Horsfall protein in three rat models with increased renal excretion of urine. Regul Pept 72: 179-186

170. Thulesen J, Poulsen SS, Jørgensen PE, Nexø E (1999) Adrenergic blockade in diabetic and uninephrectiomized rats: effects on renal size and on renal and urinary contents of epidermal growth factor. Nephron 81: 172-182 